\title{
THE IMPORTANCE OF ORIENTAL CULTS IN ANTIUM
}

Summary: This paper discusses the preliminary results of a research project, concerning Egyptian statues and Mithraic monuments, which were probably discovered in Antium and obtained by chance by local collectors or sold by antiquarians after scarcely documented excavations through the 17 th -18 th centuries.

Key words: Antium, Egyptian cults, Isis, Anubis, Serapis, Mithras

\section{ISIS PHARIA}

The focus in this section is on the importance of Antium in relation to the cult of Isis Pharia or Isis Pelagia. Like other cities of the Tyrrenian Coast, namely Ostia Pozzuoli and Cuma (where the new discoveries near the Harbour in 1992, of Egyptian statues of Isis, Naophoros, Anubis, sphynx and a bronze statue of Arpocrates, which seems to be related to a supposed Iseum with podium and lustral basin), ${ }^{1}$ a Temple of Isiac cults in Antium can also be supposed. This idea is supported, first, by the hypothesis that a statue of Isis in white marble on a boat, like Isis Pharia or Isis Pelagia, was once in the Villa Ludovisi and probably acquired by Giovanni Federico Cesi from Cardinal Ludovico Ludovisi in 1622. This statue was discovered by Bartolomeo Cesi in the 17th century in the area formerly occupied by this family and then by the

\footnotetext{
${ }^{1}$ Another Iseum is supposed near the roman Walls of the City, cf. infra n. 43; MALAISE, M.: Nova isiaca documenta Italiae. Un premier bilan (1978-2001). In BRICAULT, L. (ed.): Isis en Occident. Actes $d u 2^{\text {ème }}$ Colloque international sur les études isiaques, Lyon III, 16-17 mai 2002. Leiden 2004, Cuma, 52-53, no. 4-7, from the Necropolis comes a necklace with small Arpocrates and Isis Tyche, 53. CAPUTO, P.: Cuma. Il nuovo tempio di Iside. In GIANNElla, C. (ed.): Nova antiqua phlegraea. Nuovi tesori archeologici dai Campi Flegrei. Napoli 2000, 89-90; DE CARO, S.: Novità isiache dalla Campania. La Parola del Passato 49 (1994) 7-21, esp. 11 ff., figs 1-8.
} 


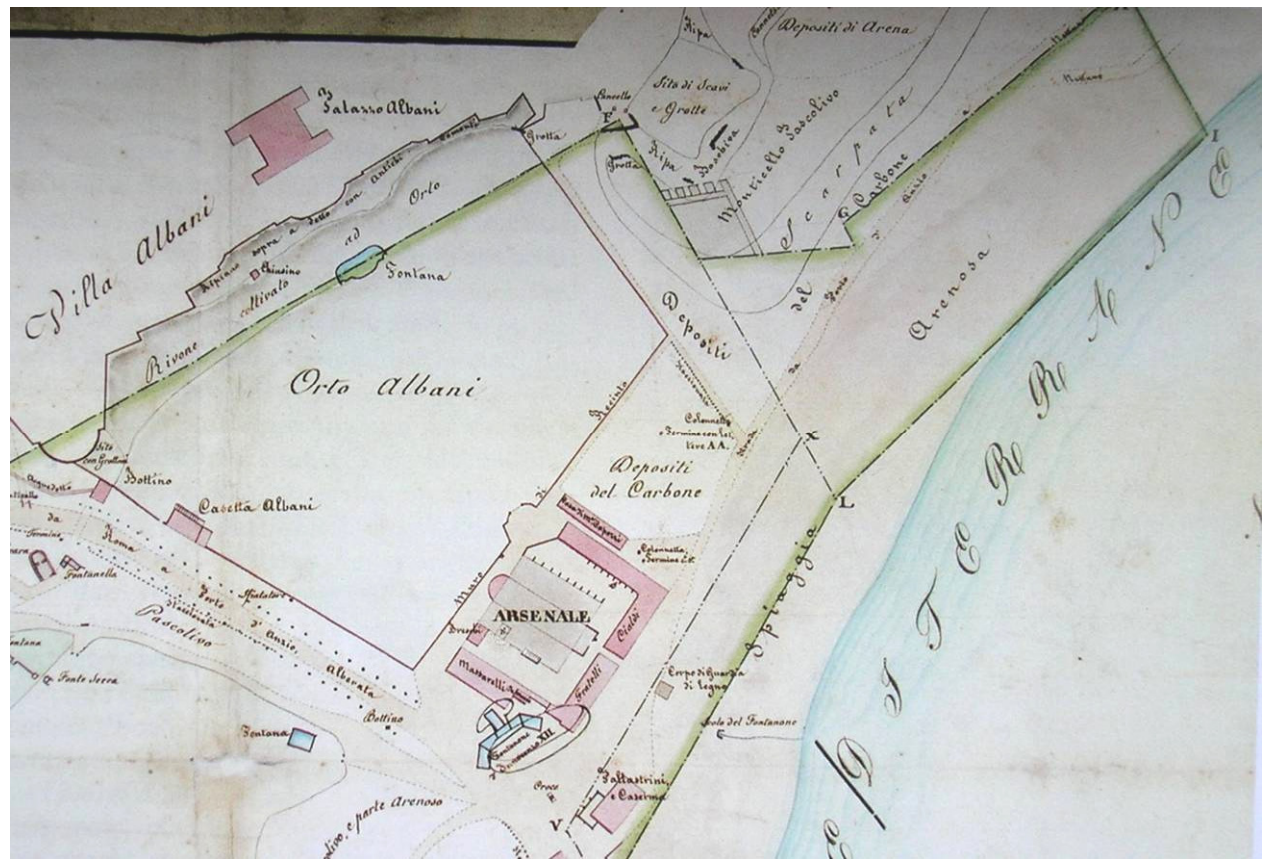

Fig. 1. Map of Anzio, Villa Albani

(BURRI, R.: Viaggio scientifico al porto neroniano e innocenziano. Roma 1847).

Pamphilj family, where archeological remains seem to be connected to an Iseum. Secondly, an oval base in grey marble was found here $(57 \times 53 \times 10 \mathrm{~cm})$. It was signed by the sculptor Athanadoros of Rhodes, son of Agesandros, and a lost statue was based on top of it, which was perhaps an Isis. ${ }^{2}$ It was found, according to Winckelmann, by Cardinal Alessandro Albani (who had settled in Antium at the beginnings of the 18th century in a land near the Cesi-Pamphilj vigna ${ }^{3}$ ) (figs 1, 6a).

A Temple dedicated to Isis Athenodoria is mentioned in Cataloghi regionari near the Caracalla's Bath ${ }^{4}$ in Rome: in Via S. Sebastiano, in front of S. Cesareo Church, there was in fact discovered a female colossal foot of a statue located on a base, decorated with sea animals, probably an Isis Pelagia Athenodoria. ${ }^{5}$

${ }^{2}$ Winckelmann, G.: Monumenti antichi inediti. Vol. I-II. Roma 1767, I 79.

${ }^{3}$ CACCIOTTI, B.: Gli scavi di antichità del cardinale Alessandro Albani ad Anzio. Bollettino dei Musei comunali di Roma, XVI (2001), 47, n. 105; 43-44, n. 49. CANEVA, G. - TrAVAGLini, C. M. (edd): Atlante storico-ambientale: Anzio e Nettuno. Roma 2003, $418 \mathrm{f}$.

${ }^{4}$ Also a mithraeum was built under the Caracalla's Baths.

${ }^{5}$ HelBIG, W. H.: Führer durch die öffentlichen Sammlungen klassischer Altertümer in Rom. Bde I-IV. Vierte Auflage, Tübingen 1963-1972, II 1523 (E. Simon); ENSOLI, S.: Culti isiaci a Roma in età tardo antica tra sfera privata e sfera pubblica. In ARSLAN, E. A. (ed.): Iside. Il mito il mistero la magia. Catalogo della mostra. Milano 1997, 915-916; EnSOLI, S. - LA RoCCA, E. (edd.): Aurea Roma. Dalla città pagana alla città Cristiana. Roma 2000, 272-273, fig. 10: S. Ensoli. From the Caracalla's bath, excavated by the Farnese family in the 16th century, could come the Farnese kneeling Naophorus with Osiris aedicula, today in the Archaological Museum in Naples, thought of unknown provenance: FORNARI 


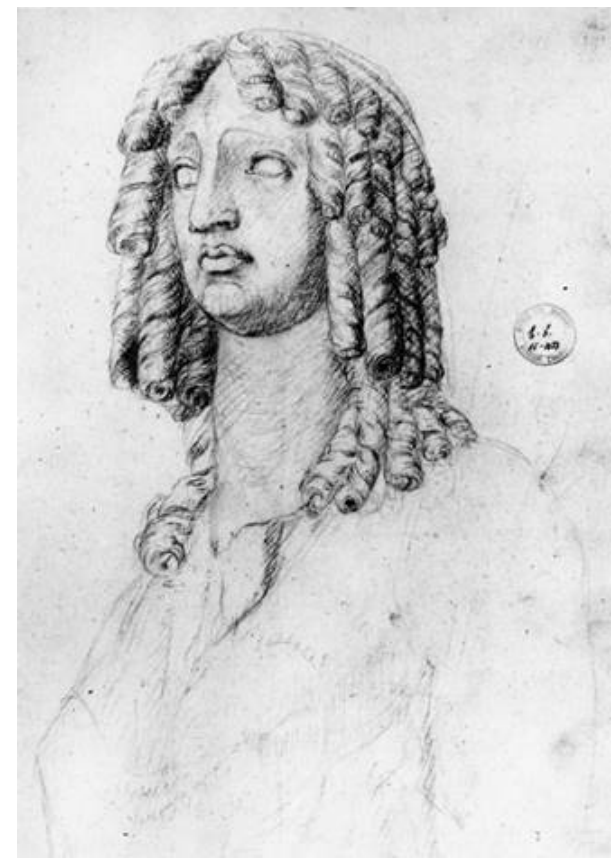

Fig. 2. Head of Ludovisi Isis, drawing of Antonio Canova

(CANDILIO, D. - PAlMA VenETUCCI, B.: Alcune novità sulla dispersione della Collezione Ludovisi. EIDOLA. International Journal of Classical Art History, Pisa-Roma 9 [2012] fig. 1).

Of particular interest is Georg Zoega's description of the little statue of Isis, in white marble with the left foot on the ship, once in Villa Ludovisi, ${ }^{6}$ also described by Winckelmann. ${ }^{7}$ The head, in white marble but not belonging to the statue, interested Canova, who drew a sketch (fig. 2); very similar to this was a fragmentary bust of

SCHIANCHI, L. - SPINOSA, N.: I Farnese. Arte e Collezionismo. Milano 1995, 406-407, no. 187. In Villa Albani a female statue on a boat, now in Paris Musée du Louvre, was known like Aphrodite Euploia: GASPARRI, C.: Die Skulpturen der Sammlung Albani in der Zeit Napoleons und der Restauration. BECK, H. BoL, P. C. (Hrsg.): Forschungen zur Villa Albani. Berlin 1982, fig. 229. AdAMO MusCETTOLA, S.: Sulla connotazione del culto di Iside a Pozzuoli. In BONACASA, N. (ed.): L'Egitto in Italia dall'Antichità al Medioevo. Atti III Congresso Internazionale Italo-Egiziano, Roma, CNR - Pompei, 13-19 novembre 1995. Roma 1998, 547-558: here 558, n. 48; BERARD, CL.: Modes de formation et modes de lecture des images

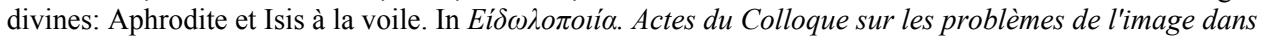
le monde méditerranéen classique. Château de Lourmarin en Provence, 2-3 septembre 1982 [Archaeologica 61]. Roma 1985, $163 \mathrm{f}$.

${ }^{6}$ PAlma Venetucci, B.: Il collezionismo di orientalia nella Roma di Pio VI. In AsCANI, K. BuZI, P. - PICCHI, D. (edd): The Forgotten Scholar: Georg Zoëga (1755-1809). At the Dawn of Egyptology and Coptic Studies. Leiden-Boston 2015, 229-230; PALMA VENETUCCI, B.: La fortuna delle sculture Ludovisi in un manoscritto di Georg Zoega. Pegasus, Berliner Beiträge zum Nachleben der Antike 18-19 (2018) 115-161.

${ }^{7}$ PALMA, B.: I marmi Ludovisi: storia della collezione. In GiUliano, A. (ed.): Museo Nazionale Romano. Le sculture I 4. Roma 1983, 153. 
Isis with Libyan ringlets (now kept in the Capitoline Museums), which was discovered in the Horti Lamiani on the Esquiline Hill; this bust could have come from the same area where the Cesi had their vineyard and where an Iseum is supposed to have been in the III Regio. ${ }^{8}$ A head in the Marsili Collection, found in Porto d'Anzio, and an Isis head with Libyan ringlets from Pozzuoli are very similar. ${ }^{9}$

This statuette, once in the Villa Ludovisi, was described by Schreiber in 1880 when she was in the stores under the Gallery of the statues, with the head of Isis but just separated from this Statue $;^{10}$ this statuette had been situated in the "Bosco delle Statue" until the middle of 19 th century, when the "Bosco" was removed. ${ }^{11}$ Bought by Leon Somzée during the dispersal of the Boncompagni Ludovisi Collection at the end of the 19th century (1896); $;{ }^{12}$ at the sale of the Somzée Collection in 1904, at the beginning of the 20th century, it was bought by Raul Warocqué, and from him it was acquired by the Museum of Mariemont, where it is today: without the ship, the statuette is $55 \mathrm{~cm} \mathrm{high}^{13}$ (fig. 3).

According to Adolf Furtwängler the statue could have had a veil moved by the wind, which would suggest an association with Isis Pharia or Isis Pelagia. ${ }^{14}$ The statue is represented in this way on a relief in Thessaloniki, ${ }^{15}$ on Delos's reliefs and clay lamps, on imperial coins of Alexandria, on a medallion of Faustina Minor with Ostia's lighthouse, and on some coins of Asia Minor, like Kyme and Iasos (where Isis is sailing on the ship with a sistrum in the right hand ${ }^{16}$ ) (fig. 4).

${ }^{8}$ CANDILIO, D. - PAlma VenetuCCI, B.: Alcune novità sulla dispersione della Collezione Ludovisi. EIDOLA. International Journal of Classical Art History, Pisa-Roma 9 (2012) 141-164; MUZZIOLI, M. P.: I luoghi dei culti orientali a Roma: problemi topografici generali e particolari. In PALMA VeNETUCCI, B. (ed.): Culti orientali, tra scavo e collezionismo. Roma 2008, 49-56, esp. 50.

${ }^{9}$ CACCIOTTI, B.: Testimonianze di culti orientali ad Antium. In PALMA Venetucci: Culti orientali (n. 8) 221-234, esp. 228, n. 28; BrizzolarA, A. M.: Le sculture del Museo civico archeologico di Bologna. La collezione Marsili. Bologna 1986, 96-97, n. 44, tavv. 87-88. DE CARO (n. 1) 7-21, fig. 14.

${ }^{10}$ SCHREIBER, T.: Die antiken Bildwerke der Villa Ludovisi in Rom. Leipzig 1880, no. 303-304: "testa di marmo bianco di Iside inferiore al vero, forse non antica"; cf. Il Museo Pio-Clementino. Illustrato e descritto da GiamBatTista ed EnNio Quirino VisCONTI. Vol. I-VII. Milano 1807 ff., VI 1819, tav. 17.

${ }^{11}$ PALMA (n. 7) 171. In the "Bosco delle Statue" the statue is not mentioned in the inventories, a statue is described with the rudder as the goddess of navigation: PALMA (n. 7) 77-78, no. 212, in "Magazzini" was described by SCHREIBER (n. 10) no. 301. Today in the USA Embassy, 1.25 m high: PAlmA, B. - DE LACHENAl, L. - Micheli, M. E.: I marmi Ludovisi dispersi. In GiUlianO, A. (ed.): $M u$ seo Nazionale Romano. Le sculture I 6. Roma 1986, VII 16: L. de Lachenal.

${ }^{12}$ Palma (n. 7) 188.

${ }^{13}$ FAYDER FEYTMANS, G.: Les antiquités égyptiennes, grecques, étrusques, romaines et gallo-romaines du Musée de Mariemont. Bruxelles 1952, G 39, tav. 26. PALMA - DE LACHENAL - Micheli (n. 11) II $34,73$.

${ }_{14}^{14}$ FURTWÄNGLER, A.: Sammlung Somzée, antike Kunstdenkmäler. München 1897, no. 51, fig. 51.

${ }^{15}$ Blanchard, M. H.: Un relief Thessalonicien d'Isis Pelagia. Bulletin de Correspondance Hellénique 108 (1984) $709 \mathrm{f}$.

${ }^{16}$ DelRIEUX, F.: Les temoignages isiaques sur les monnaies grecques de Carie et d'Ionie aux epoques hellenistique et romaine. In BRICAULT, L. (ed.): Isis en Occident. Actes du II Colloque international sur les etudes isiaques, Lyon III, 16-17 mai 2002. Leiden 2004, 340, fig. 3; PALMA VENETUCCI, B.: Culti egizi da Iasos ad Antium. In Scritti in memoria di Doro Levi. Annuario della Scuola Archeologica Italiana di Atene, forthcoming. 


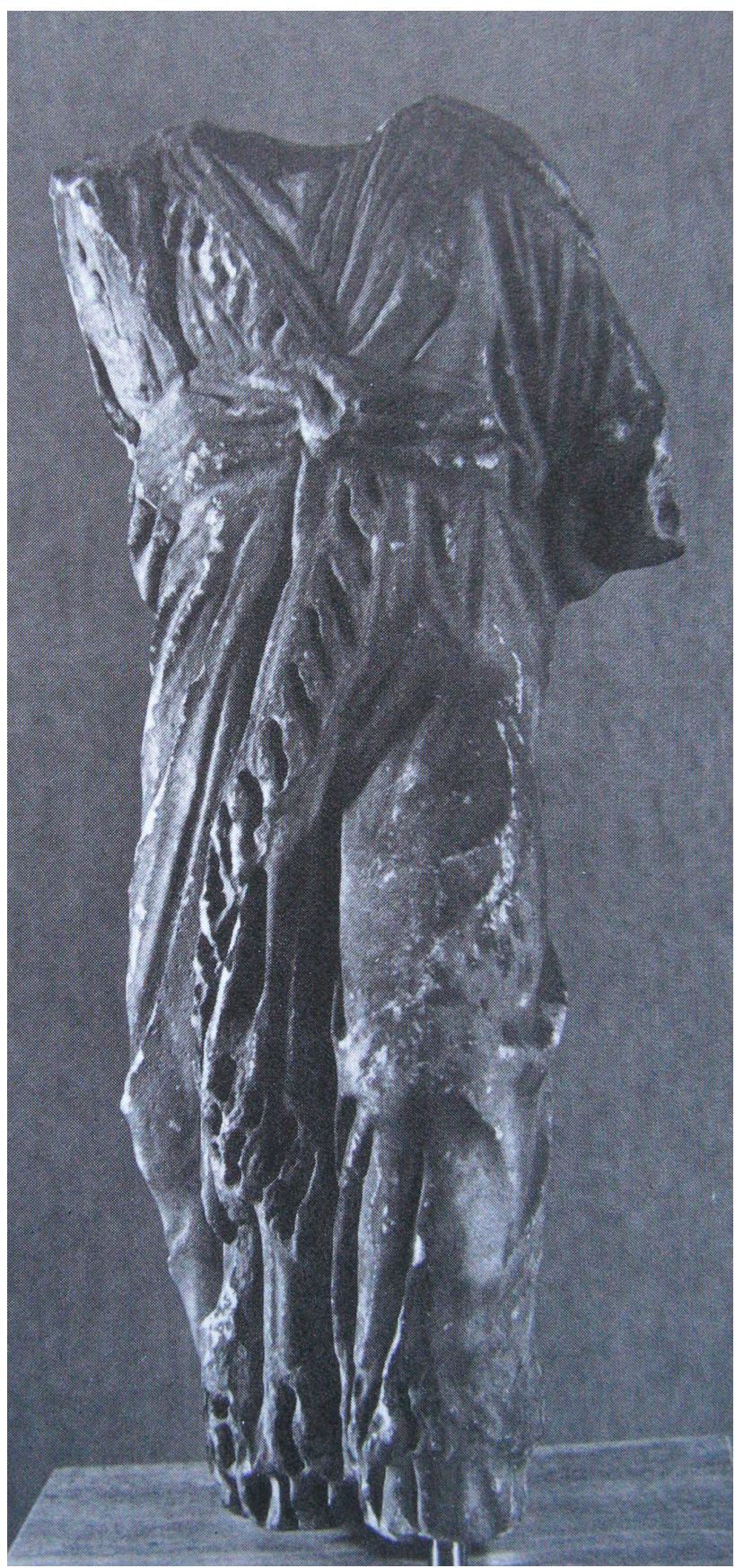

Fig. 3. Statuette of Ludovisi Isis. Mariemont Museum

(PAlma, B. - DE LACHENAL, L. - Micheli, M. E.: I marmi Ludovisi dispersi.

In GiUliano, A. [ed.]: Museo Nazionale Romano. Le sculture I 6. Roma 1986, no. II, 34). 


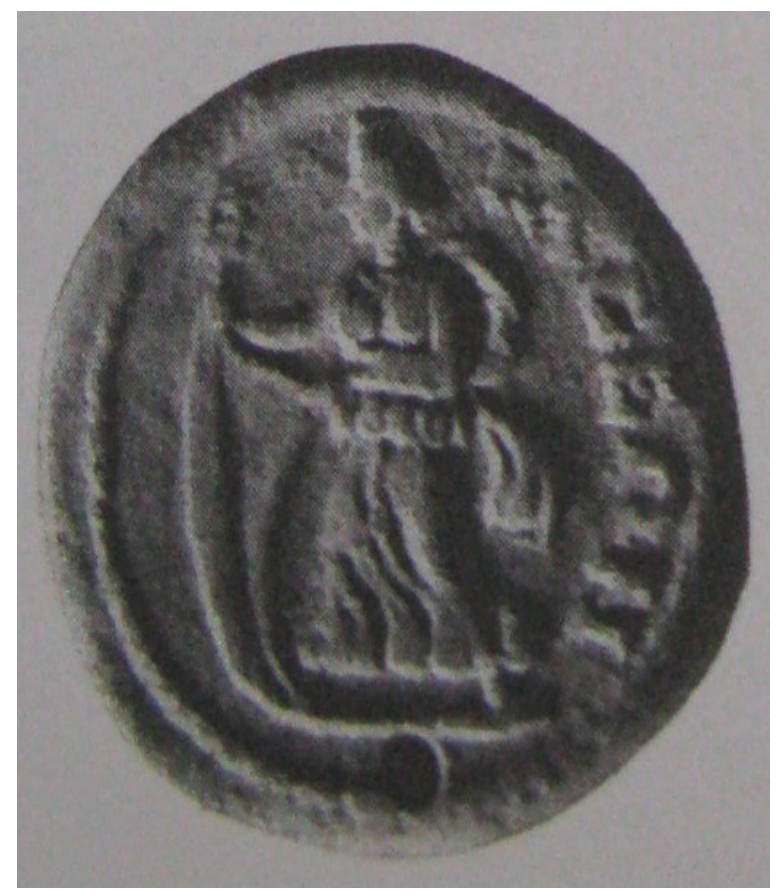

Fig. 4. Coin with Isis Pelagia, Iasos (DELRIEUX, F.: Les temoignages isiaques sur les monnaies grecques de Carie et d'Ionie aux epoques hellenistique et romaine.

In BRICAULT, L. [ed.]: Isis en Occident. Actes du II Colloque international sur les etudes isiaques, Lyon III, 16-17 mai 2002. Leiden 2004, 340, fig. 3).

Giuseppe Pucci, ${ }^{17}$ who examines the statues of Mariemont (while ignoring the fact that the statue was on the ship), of Budapest, ${ }^{18}$ of Benevento (where only the boat with the foot of Isis is preserved ${ }^{19}$ ) and of Ostia, ${ }^{20}$ has concluded, contrary to Bruneau, that they are all copies of an Hellenistic original of Isis Pelagia, ${ }^{21}$ together with the Borghese and Torlonia statues, both restored to look like Ceres. ${ }^{22}$ Stefania

${ }^{17}$ PUCCI, G.: Iside Pelagia: a proposito di una controversia iconografica. Annali della Scuola normale superiore di Pisa ser. III, 6.4 (1976) 1177-1191.

${ }_{18}$ Probably from Pausillypon, (Naples) where also a basalt naophorus was found, discovered in the villa maritima at the beginnings of the 20th century, today in Naples, National Museum; cf. SZILÁGYI, J. GY.: Un problème iconographique. Bulletin du Musée Hongrois de Beaux Arts 32 (1969) 19-30; DE CARO (n. 1) 13, figs 9-11.

${ }^{19}$ From the Iseum in Benevento also come some bidders kneeling resembling those linked to "Fortuna" in Palestrina. MüLlER, H. W.: Il culto di Iside nell'antica Benevento. Catalogo delle sculture provenienti dai santuari egiziani dell'antica Benevento nel Museo del Sannio. Benevento 1971.

${ }^{20}$ HeLbig (n. 5) IV 3387 (F. Zevi); F. ZEVI in Iside (n. 5) 322-323.

${ }^{21}$ BrunEaU, P.: Isis Pelagia a Délos. Bulletin de Correspondance Hellénique 85 (1961) 435 ff., Bruneau, P.: Isis Pelagia a Délos. Compléments. In Bulletin de Correspondance Hellénique 87 (1963) 301-308.

${ }^{22}$ We do not know where these statues were discovered but the Borghese family acquired in the 19th century the Pamphilj's Villa in Anzio and had also another important Villa in Nettuno (CANEVA- 
Adamo Muscettola, examining a similar statue from Pozzuoli, has distinguished the type of Isis Pharia, where the goddess is in a frontal position, with the foot resting on the bow of a ship while the coat forms a large bow at its back, from that of Isis Pelagia sailing. ${ }^{23}$

Of particular interest is the connection of our Isis Ludovisi with the cult of Isis Pelagia, as supposed in Antium. The Ludovisi statue might indeed have come from the Cesi collection, acquired in part in 1622 by Cardinal Ludovico Ludovisi. This statuette may perhaps be identified with one of the little statues mentioned in the inventory of the Roscioli notary, listing the sculptures sold by Giovanni Federico Cesi to Cardinal Ludovisi. ${ }^{24}$

The Isis statuette appears to have been excavated by Monsignor Bartolomeo Cesi of Acquasparta who had acquired land at Porto d'Anzio in 1615, where he built a villa and collected many antiquities discovered in the area. ${ }^{25}$ After his death in 1621 , his property was assigned to Federico, the first duke of Acquasparta, who tried to establish a botanical garden in the villa, and then to Giovanni Federico Cesi III, who sold the Villa to Camillo Pamphilj in $1645 .^{26}$ Can we suppose that one of the sphynxes and one of the Serapis heads in Villa Pamphilj in Rome, were found in Antium and could be related to a supposed Iseum? (fig. 5). ${ }^{27}$ In the area of villa Pamphilj, known as Villa Pia-Adele, now an archaeological museum, where the statue of Anubis was discovered in the 18th century, according to many scholars (Brandizzi Vittucci as an example) it was a temple of Isis, near the eastern border of the Villa,

TRAVAGLINI [n. 3] 427-428); the Torlonia Sculptures in part were acquired by Giustiniani or by Albani collectors (CACCIOTTI [n. 3]), in part were discovered in Porto (Ostia): many inscriptions dedicated to Isis and Serapis were discovered during the Torlonia excavations in Porto and also a Bes in Porphyry: Malaise (n. 1) 25, no. 16 c, d, e; PAlma Venetucci, B.: Bes tra gli Aegyptiaca degli studioli rinascimentali. In Atti dell' Incontro di Studio in ricordo di Sabatino Moscati, Roma, 7-8 novembre 2007 [Atti dei Convegni Lincei 244]. Roma 2009, 164.

${ }^{23}$ AdAmo MuscetTola (n. 5) 547. Also a kneeling naophorus with Osiris aedicula, was found in Pozzuoli, then donated to the Museo Nazionale di Napoli, cf. La Collezione Egiziana del Museo Archeologico Nazionale di Napoli. Napoli 1989, 149, no. 15, 48, probably from a small temple dedicated to the Egyptian gods near the crossroad of the Annunziata; DE JORIO, A.: Guida di Pozzuoli e contorni. Napoli 1822, 85 ff., tav. III, and also a head of Isis, cf. DE CARO (n. 1), figs 13-14. Heike Gregarek distinguish between the type of Isis Pharia (whose name comes from the Lighthouse of Alexandria) or Isis Pelagia (represented by Borghese and Torlonia statues) and the Isis-Tyche (by the statues of Palestrina and Ostia), cf. GREGAREK, H.: Untersuchungen zur kaiserzeithlichen Idealplastik aus Buntmarmor. Kölner Jahrbuch für Vor-und Frühgeschichte 32 (1999) 79-80.

${ }^{24}$ PALMA (n. 7) 36-37, no. 5; also the "cinocefalo", dog-headed in grey marble could come from Anzio: in fact it is already mentioned in 1623 in the first inventory Ludovisi, no. 11, no. 35, and in the 19th century also "nei Magazzini” near the statue and head of Isis. SCHREIBER (n. 10) no. 305.

${ }^{25}$ CANEVA-Travaglini (n. 3) 410, n. 263, "inventario delle robbe, che sono nella Villa di Anzio dell'Ecc.mo F. Duca Cesi", where there are unfortunately mentioned only barrels and wine tools. PUCCILLO, C.: Anzio delle delizie: le dimore nobiliari, itinerari storico-artistici tra le ville cardinalizie attraverso documenti inediti. Pomezia 1997, 22-23.

${ }^{26}$ CACCIOTTI (n. 3) 47, n. 104. BRANDIZZI VitTUCCI, C.: Anzio delle delizie: le dimore nobiliari, itinerari storico-artistici tra le ville cardinalizie attraverso documenti inediti. Pomezia 2000, 11, n. 24, 51-52. CANEVA-Travaglini (n. 3), 417 f.

${ }^{27}$ CAlZA, R. (ed.): Antichità di Villa Doria Pamphilj. Roma 1977, no. 81, 82, 109-110. 


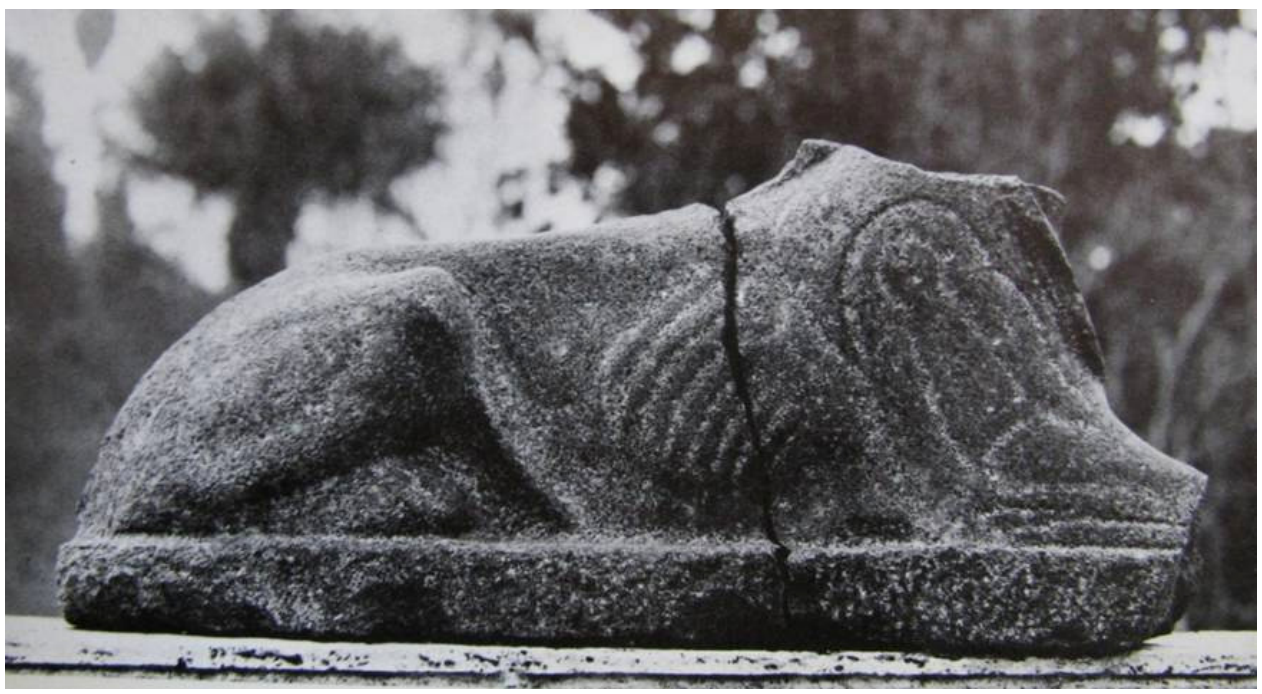

Fig. 5. Statue of Sphynx. Rome, Villa Doria Pamphilj

(CAlZA, R. [ed.]: Antichità di Villa Doria Pamphilj. Roma 1977, no. 110).

on via Gramsci, approximately where on the plan the Roman thermae can be seen: ${ }^{28}$ the Isiac rites of purification avoided water. ${ }^{29}$ Another little temple of Isis is thought to have been located near the Arco Muto, in connection with the imperial Villa because a large head of Isis was discovered here in $1913 .^{30}$ (Beatrice Palma Venetucci)

\section{ISIACA}

Although there is no ground evidence of structures related to an Iseum in Antium, however, we can reflect on the possible cult of Isis here.

First of all we can underline the condition of port city, which is a favourable position for the reception of foreign cults.

In fact the first Egyptian sanctuaries were built near harbour towns (Puteoli, Cumae, Ostia), where the Italic merchants who had worked at Delos, the main path channel for the spread of the cult of Isis to Italy, used to pass by. ${ }^{31}$ There is also

${ }^{28}$ CANEVA-Travaglini (n. 3) 150.

${ }^{29}$ BRANDizZI VitTUCCI (n. 26) 51. CELLINI, G. A.: I materiali scultorei provenienti da Antium nelle fonti antiquarie [Atti della Accademia nazionale dei Lincei. Classe di scienze morali, storiche e filologiche. Rendiconti, ser. 9, v. 21]. Roma 2012, 663-734, esp. 696-697.

${ }^{30}$ Di MARIO, F. - JAIA, A. M.: Anzio. Scavi e ritrovamenti della prima metà del Novecento nell'Archivio della Soprintendenza per i Beni archeologici del Lazio. In SAPELLI RAGNI, M. (ed.): Anzio e Nerone: tesori dal British Museum e dai Musei Capitolini. Roma 2009, 56-59.

${ }^{31}$ MalAise, M.: Les conditions de pénétration et de diffusion des cultes égyptiens en Italie. Leiden 1972, 281 ff.; Leclant, J.: Prefazione. In Iside (n. 5) 19-27, esp. 20 ff.; PoOLE, F.: Il Culto di Iside a Pompei. In Senatore, F. (ed.): Pompei, Capri e la penisola Sorrentina. Atti del quinto ciclo di conferenze 
a noticeable relationship with Delos by negotiatores native from Antium. ${ }^{32}$ The city, however, was the landing place of Praeneste's trades and was the passage for new religions through the inland, as, for example, the syncretism of Isis Tyche and Fortuna Primigenia and the introduction of Isis Pelagia, the patron of navigation, in the sanctuary of Praeneste. ${ }^{33}$

We have evidence of the Isiac cult from the archaeological discoveries of the past.

In $1749,{ }^{34}$ in a land owned by the Pamphilj family (fig. 6a), the statue of Anubis, now preserved in the Vatican Museums, in the Gregorian Egyptian Museum (fig. 6b) was discovered. ${ }^{35}$ The dog-headed deity is represented as Mercury with a palm-trunk support. The forehead bears a crescent moon on which there is a disk. This disk could be interpreted either as a sun or as a full moon: this would be a way to represent the facies nunc atra nunc aurea that characterises the appearance of Anubis described by Apuleius (his face black or gold with obvious relationship to the Underworld and Superi). ${ }^{36}$

di geologia, storia e archeologia. Capri 2004, 221, 242; MALAISE: Nova Isiaca (n. 1) 41; CACCIOTTI: Testimonianze (n. 9); NiElSEN, I.: Housing the Chosen: The Architectural Context of Mystery Groups and Religious Associations in the Ancient World. Turnhout 2014, 68.

${ }^{32}$ Some funerary inscriptions from Antium (CIL X 6672, 6737, etc.; CIL I alt. ${ }^{4} 3041$, CIL X 6674, 6736; BRANDIZZI VITTUCCI (n. 26) 144-145 and n. 689) bear names that recall those of the negotiatores in Delos: Nonius, Munatius, Mynucius (MALAISE: Les conditions (n. 31) 292, no. 48: Nonni, Serapeo C.).

${ }^{33}$ Champeaux, J.: Fortuna. Recherches sur le culte de la Fortune à Rome et dans le monde romain des origines à la mort de César. 1: Fortuna dans la religion archaïque [Collection de l'École française de Rome 64]. Roma 1982, 149 ff.; COARELLI, F.: I santuari del Lazio in età repubblicana. Roma 1987, 75 ff.; RIEMAnN, H.: Praenestinae sorores, Tibur, Ostia, Antium. Römische Mitteilungen 94 (1987) 131-162, esp. 139 ff.; TORTORELLA, S.: Sacrificium in aede Fortunarum? Documenta Albana ser. II, 10 (1988) 39-46, esp. 43; COARELli, F.: Iside e Fortuna a Pompei e Praeneste. In: Alla ricerca di Iside. Giornata di studi, Napoli = La parola del passato 49 (1994) 119-129, esp. 123; G. SFAMENI GASPARRO, G.: Iside Fortuna: fatalismo e divinità sovrane del destino nel mondo ellenistico-romano. In: Le Fortune dell'età arcaica nel Lazio ed in Italia e loro posterità. Atti del $3^{\circ}$ Convegno di studi archeologici, Palestrina 15-16 ottobre 1994. Palestrina 1996, 301-323; LECLANT: Prefazione (n. 31), 24; CACCIOTTI: Testimonianze (n. 9) 225-226; CAPRIOTTI VITTOZZI G.: L'Egitto a Praeneste: alcune note. Mediterranea 6 (2009) 79-97; BRICAULT, L.: Les cultes isiaques dans le monde gréco-roman, Paris 2013, 486, 493-499; AGNOLI, N.: Museo archeologico nazionale di Palestrina, Le sculture. Roma 2002, 24-25, 89-93, Cat. I 21. The association between the statues cult of Isis Pelagia and the harbour towns had been lastly investigated by BRICAULT, L.: Isis, dame des flots, Liège 2006, 86-99.

34 "Nell'anno 1749 nella villa Panfili presso Anzio, si trovò una statua d'Anubi in figura, e abito all'eroica, col sistro nella mano destra, e il caduceo nella sinistra, e un fiore di loto alle orecchie." Cf. Notizie di antichità ricavate dalle opere dell' Ab. Francesco Ficoroni. In FEA, C.: Miscellanea filologica critica e antiquaria. Roma 1790, I p. CLXV, n. 95.

${ }^{35}$ BotTI, G. - Romanelli, P.: Le sculture del Museo Gregoriano Egizio. Città del Vaticano 1951, 119, 141, no. 188, tav. LXXX.

${ }^{36}$ ApULEIUS, Metamorphoses XI 11. 1. In Egyptian sources Anubis is shown while rolling the disk of the Moon in front of him (JUNKER, H. - WINTER, E.: Das Geburtshaus des Tempels der Isis in Philä. Wien 1965, 104 fig. 930, 105, n. 10; GWYN GRIFFITHS, J.: Apuleius of Madauras. The Isis-Book (Metamorphoses, Book XI) [ÉPRO 39]. Leiden 1975, 217). 


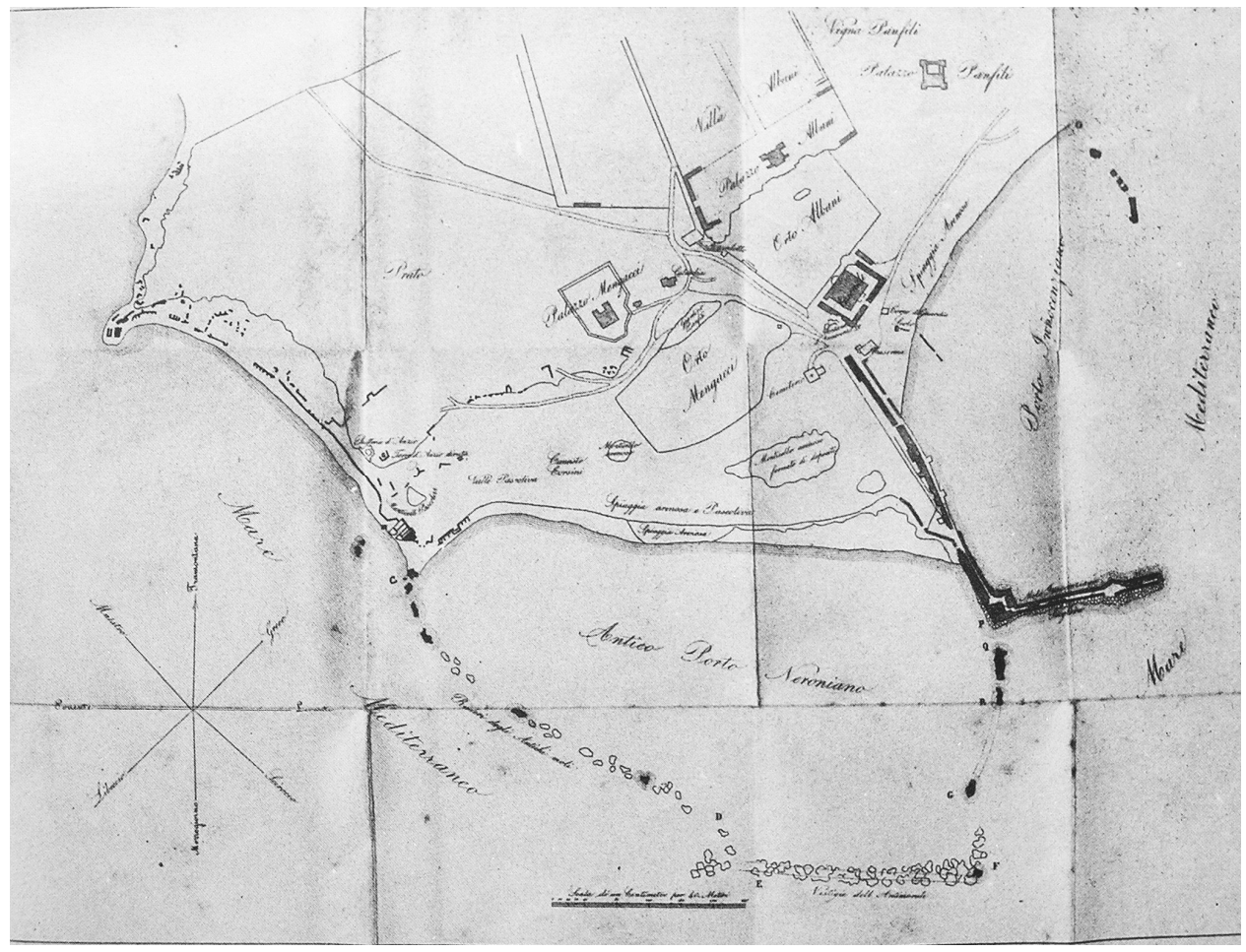

Fig. 6a. Map of Antium, Villa Pamphilj

(from BURRI, R.: Viaggio scientifico al porto neroniano e innocenziano, Roma 1847).

The statue wears half-boots, rather typical of Anubis warrior, which might have been carved by Clemente Bianchi, who restored it in $1750 .{ }^{37}$ With his left hand he holds a caduceus around which is wrapped a snake, in his right hand remaines the handle of a sistrum. The sistrum was completely reconstructed, together with the forearm, by the restorer, but then it was lost. ${ }^{38}$ The sistrum is not otherwise documented in sculpture: this attribute characterises the divinity in some gems and in the 4th century coins issued for Vota Publica. ${ }^{39}$ In addition to caduceus, more often the God holds a green palm: in this case it is represented by the support. ${ }^{40}$ The ritual

37 "per aver fatto il modello al braccio destro con il sistro in mano": BARBERINI, M. G.: Clemente Bianchi e Bartolomeo Cavaceppi 1750-1754: restauri conservativi ad alcune statue del Museo Capitolino. Bollettino dei Musei Comunali di Roma 8 (1994) 99-102, esp. 95 ff.

${ }^{38}$ LeClant, J. s.v. Anubis in LIMC I (1981) 862-873, esp. 866, n. 27; GrenIER, J. Cl.: Museo Gregoriano Egizio. Roma 1993, 42, no. IV.7, tav. 12. We do not agree with the opinion of BOTTI- ROMANELLI (n. 35) 119, no. 188, tav. LXXX, who hypothesized a palm tree in the hand, instead the palm is indicated by the trunk of support.

39 Bonner, C.: Studies in Magical Amulets. Ann Arbor 1950, 259, no. 42; 260, no. 43; LECLANT: Anubis (n. 38) 866, no. 26.

${ }^{40}$ The "palma virens" is quoted by Apuleius, Metamorphoses XI 11. For Anubis with the palm see: GRENIER, J.-CL.: Anubis alexandrin et romain [ÉPRO 57]. Leiden 1977, 147 f., no. 227, tav. XIX; 


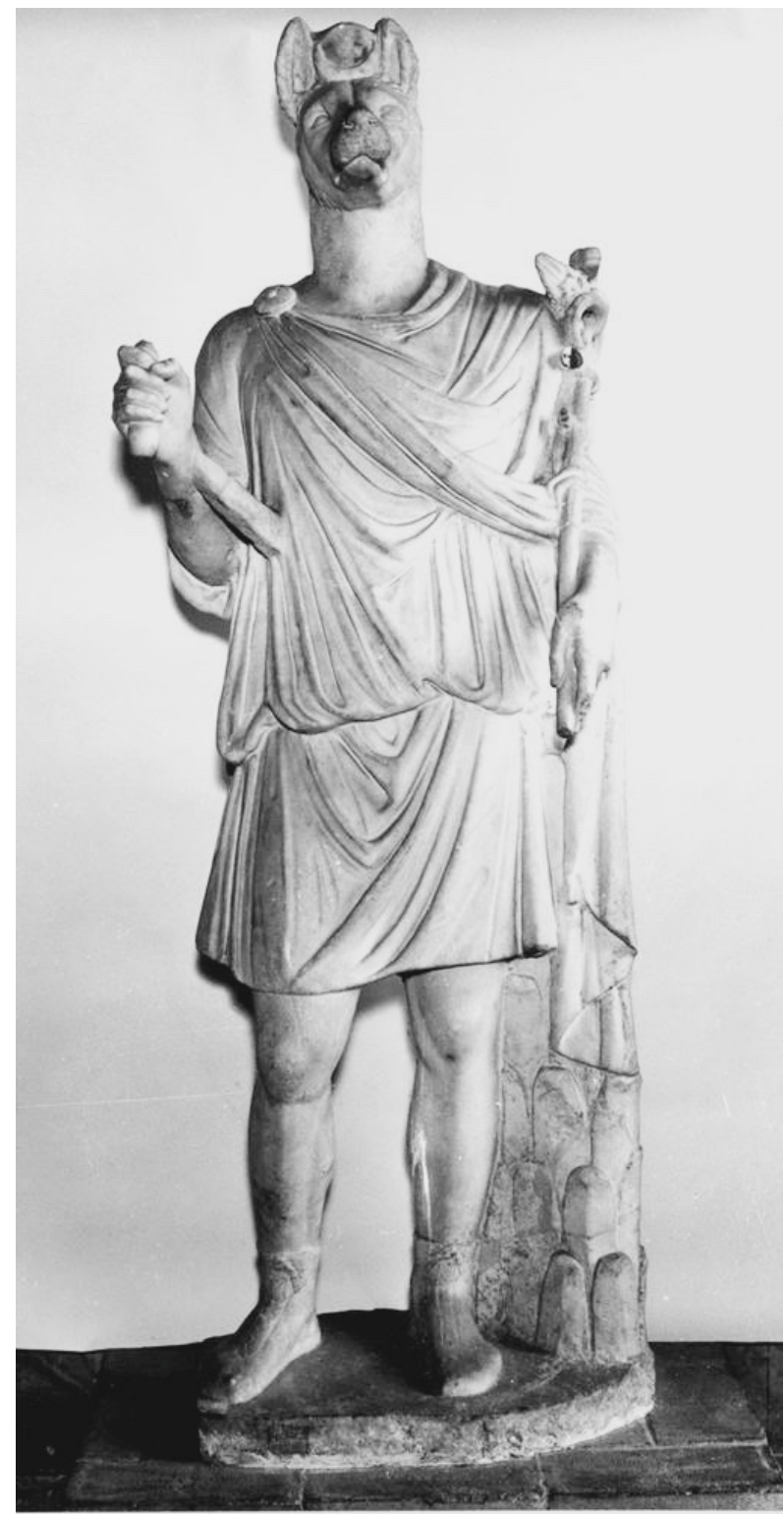

Fig. 6b. Statue of Anubis from Antium. Vatican Museums, Museo Gregoriano Egizio (CACCIOTTI, B.: Testimonianze di culti orientali ad Antium. In PAlma VenetucCi, B. [ed.]: Culti orientali, tra scavo e collezionismo. Roma 2008, 232, fig. 2).

GRENIER, J.-CL.: L'autel funeraire isiaque de Fabia Stratonice [ÉPRO 71]. Leiden 1978, 6-7, tavv. IVV; LEMBKE, K.: Das Iseum Campense in Rom. Studie über den Isiskult unter Domitian. Heidelberg 1994, 245, no. 49, tav. 46). J. BELTRÁN FORTES, J.: Cultos orientales en la Baetica romana. Del coleccionismo a la Arqueología. In PALMA VENETUCCI: Culti orientali (n. 8) 251. 
instrument, with the caduceus, is attributed to Isiac priests in two Pompeian paintings. $^{41}$

Anubis is a member of "Isiac family". It was worshipped in the Serapei A and $\mathrm{C}$ of Delos , in the Isei of Gortyna, ${ }^{42}$ Cuma and probably of Beneventum. ${ }^{43} \mathrm{He}$ had to have a niche with Harpocrates in the Iseum of Pompei; always with Harpocrates, he was represented on the altar dedicated to Isis, which was discovered in the Iseum of the Campus Martium and he was depicted on some altars and lamps from Ostia. ${ }^{44}$

The clear manifestation of the cult for a dog-headed god documented at the Isei by the above mentioned archaeological discoveries, the symbol of the sistrum in his right hand, its great measurements $(1.55 \mathrm{~m})$ and the typological convergence with the statue of Cuma ${ }^{45}$ (fig. 6c) (also next to a palm trunk and with the caduceus in his left, now lost) would support the hypothesis that the Anubis Pamphilj belonged to a religious context.

A finding of the first half of the 18th century is more directly connected to the local context and the risks of the sea: it is a relief with Anubis dedicated by the freedman Agathemerus to Isis and Anubis for his happy return home ([Isidi et Anub]i dis feci[t ille] Agatheme[r libertus]. [Rurs]us hinc (= huc) redduciti (= -ite) Ve [---] tum ${ }^{46}$ (fig. 6d). The role of Anubis to protect people travelling, alone or associated with Isis Pelagia or Pharia, is documented by Roman coins of Constantine period. ${ }^{47}$ On these coins is depicted Anubis on a bow of the ship instead of Isis. The votive nature of the relief suggests a public display.

A bust of Serapis $(1.43 \mathrm{~m}$ high although the measures are inclusive of restorations) also suggests a religious setting of some importance: it is said that it was found

${ }^{41}$ Tran Tam Tinh, V.: Essai sur le culte d'Isis à Pompéi. Paris 1964, 128, no. 14, tav. XVI,2, 138 ss., no. 40, tav. VI; Iside (n. 5) 340 (S. De Caro); CACCIOTTI: Testimonianze (no. 9) 223-224.

${ }^{42}$ A significant number of epigraphic documents related to Anubis come from Delos. GRENIER: Anubis (n. 40) 140-144, no. 212, tav. XV (Delos), no. 216 (in Gortyna Anubis was found in situ with Isis and Serapis); LECLANT: Anubis (n. 38) 867, no. 38, 871; BRICAUlT: Les cultes (n. 33) 49-54; POOLE (n. 31) 221-222; NIELSEN (n. 31), 66.

${ }^{43}$ The Anubis discovered in Cuma near the north city wall in 1846 is different from the statue found on the south coast of the Acropolis. Here in 1992 were found the statues of Isis, Naophoros, Anubis, Sphynx, a small bronze statue of Arpocrates and some fragments of statues. They seem to be related to an Iseum of which have been digged the podium and a lustral basin. From a necropolis of Cuma comes a necklace with the images of a small Arpocrates and Isis - Tyche (CAPUTO (n. 1) 89-90; MALAISE: Nova isiaca (n. 31) 32-33, no. 4-7, 42, 46. For Beneventum see: MülLER (n. 19) 82-84, no. 281, tav. XXVIII; GRENIER: Anubis (n. 40) 143-144, no. 220 (with different iconography).

44 Tran TAM Tinh (n. 41) 88; Poole (n. 31) 227; LeMBKe (n. 40) 245, no. 49, tav. 46 (Rome); MALAISE, M.: Inventaire préliminaire des documents égyptiens découverts en Italie. Leiden 1972, 84, no. $101 ; 86$, no. 113 (Ostia).

${ }^{45}$ GrENIER: Anubis (n. 40) 141, no. 214, tav. XVII; Iside (n. 5) 449, cat. V. 80 (R. Di Maria); Walker, S. - Higgs, P. (edd): Cleopatra Regina d'Egitto. Catalogo della mostra, Roma 2000-2001. Milano 2000, 243, no. IV 15 (C. Alfano).

${ }^{46}$ MALAise: Inventaire (n. 44) 57, no. 1; LeClAnT: Anubis (n. 38) 864, no. 2; Solin, H.: Contributi sull'epigrafia anziate. Epigraphica 65 (2003) 69-116, esp. 80-89; CACCIOTTI: Gli scavi (n. 3) 58-59, n. 120; CACCIOTTI: Testimonianze (n. 9) 221-234, fig. 4. BRANDIZZI ViTTUCCI (n. 26) 51-52.

${ }^{47}$ AlFÖLDI, A.: Festival of Isis in Rome under the Christian Emperors of the Fourth Century. Budapest 1937, 61, no. 13; MALAISE: Les conditions (n. 31) 209. 


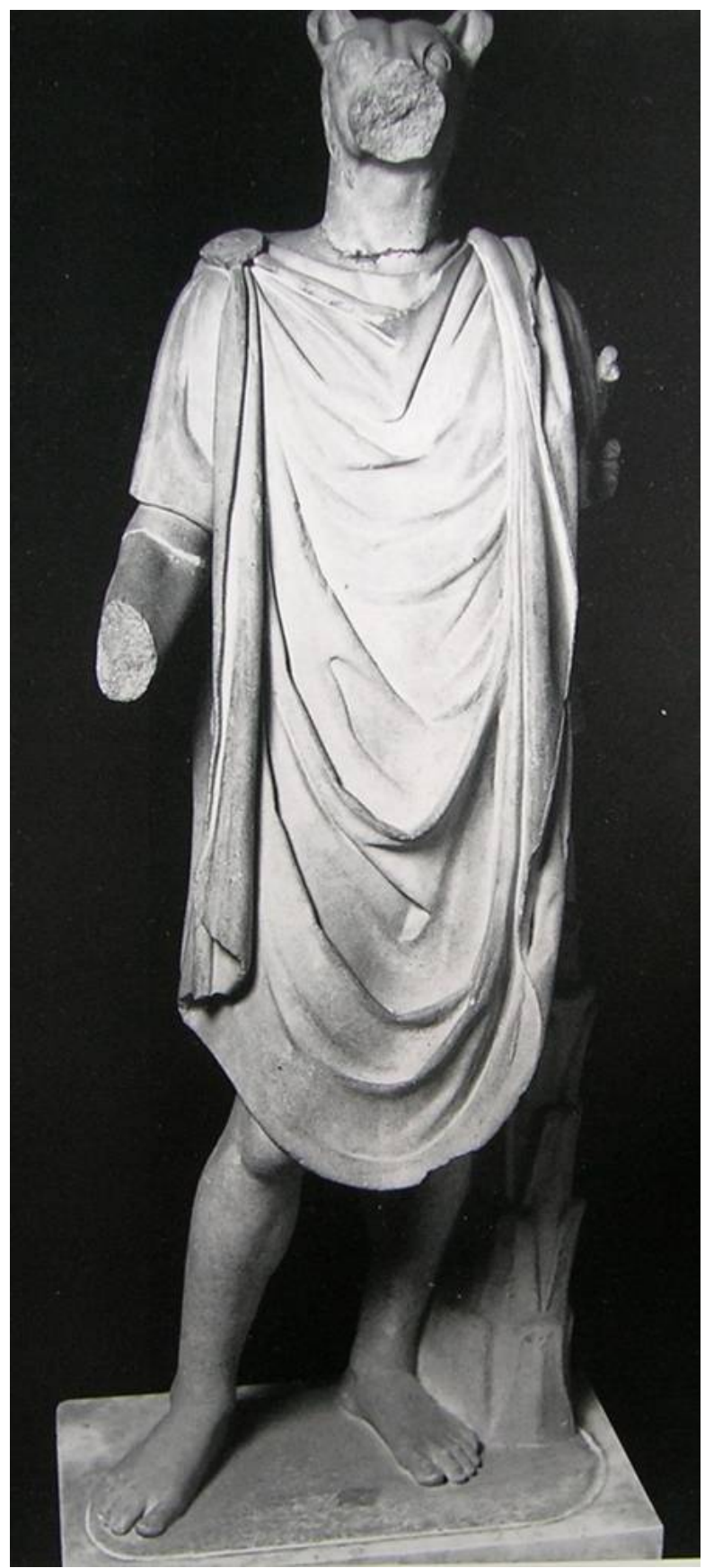

Fig. 6c. Statue of Anubis from Cuma. Napoli, Museo Archeologico Nazionale (WALKeR, S. - HigGS, P. [edd]: Cleopatra Regina d'Egitto.

Catalogo della mostra, Roma 2000-2001. Milano 2000, 243, no. IV 15). 


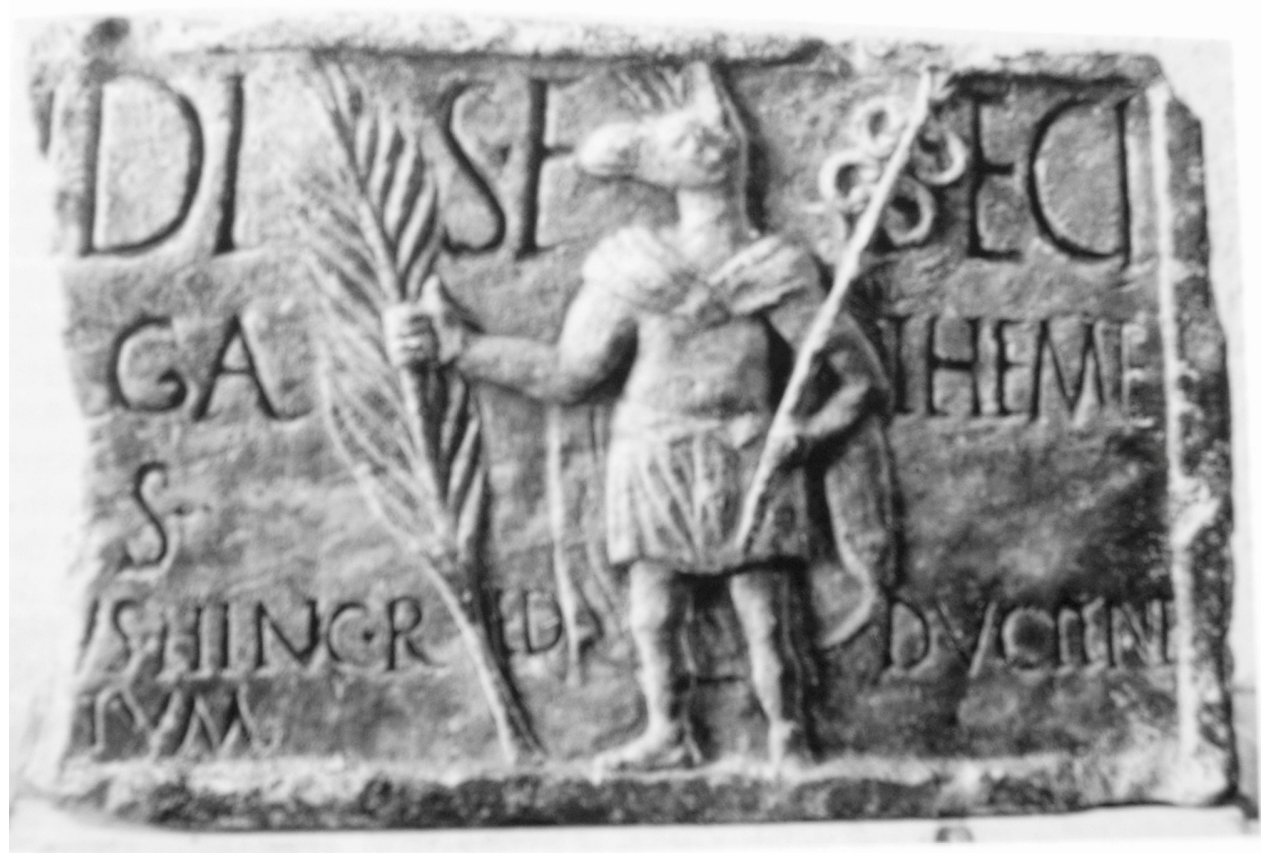

Fig. 6d. Votive relief with Anubis from Antium. Paris, Musée du Louvre (SOLIN, H.: Contributi sull'epigrafia anziate. Epigraphica 65 [2003] 69-116, fig. 1).

in Antium and at the present time it is preserved in Palazzo Torlonia alla Lungara (fig.7a), but it seems that it belonged to the 17th-century Giustiniani Collection (fig. $7 \mathrm{~b})$. $^{48}$

An Isiac context can be evoked through a priest basalt statue (fig. 8) moved to England (Brockelsby Park) by Richard Worsley. According to this we can trace the origin thanks to the testimony of Ennio Quirino Visconti. ${ }^{49}$ The figure, with a shaved head, is in standing position with his left leg forward; it wears a shenti, his arms are held straight along his sides and his hands are clenched into fists. It is located on a parallelepiped socket and leans against a back pillar ending with a pyramidion. The hieroglyphic inscription on the back is shown by the engraving of Visconti in an approximate manner and so it is not understandable. Therefore we can agree with the Visconti's interpretation of the priest of Isis. It is a very common iconography, as shown by some comparisons: for example a statue in red granite belonged to Henry Blundell Collection, a piece of a private collection in New York and the marble head preserved in the National Archaeological Museum in Rome. The last

${ }^{48}$ CACCIOTti: Gli scavi (n. 3) 59 and n. 123. CACCIOTTI: Testimonianze (n. 9) 227, fig. 9.

${ }^{49}$ Visconti, E. Q.: Il Museo Worsleyano descritto con prefazione di G. Labus. Roma 1834, $74 \mathrm{ff}$; CACCiOTTI: Gli scavi (n. 3) 59; CACCiOTTI: Testimonianze (n. 9) 227, fig. 10. 


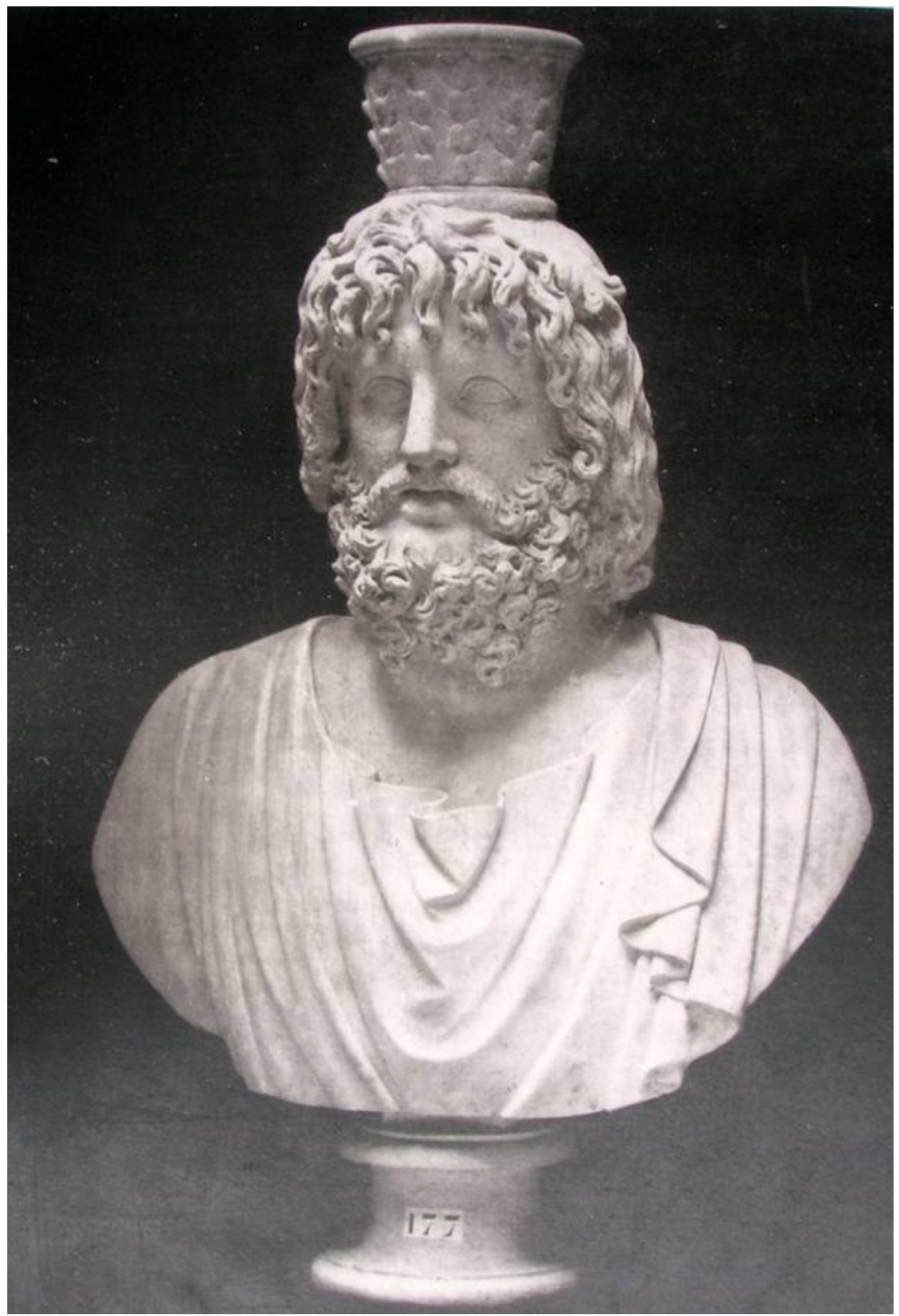

Fig. 7a. Bust of Serapis from Porto d'Anzio. Rome Torlonia Palace

(VISCONTI, C.L.: I monumenti del Museo Torlonia riprodotti con la fototipia. Roma 1885, tav. XLV).

two copies are dated to the Ptolemaic Period and the Worsley priest dates to the same period. $^{50}$

${ }^{50}$ Roullet, A.: The Egyptian and Egyptianizing Monuments of Imperial Rome [ÉPRO 20]. Leiden 1972, 124, no. 241, fig. 248; VON Bothmer, B.: Egyptian Sculpture of the Late Period 700 B.C. to A.D. 100. Catalogue of the Brooklyn Museum. New York 1960, 168-169, no. 129, figs 322-323; Iside (n. 5) 169, no. IV.17. 


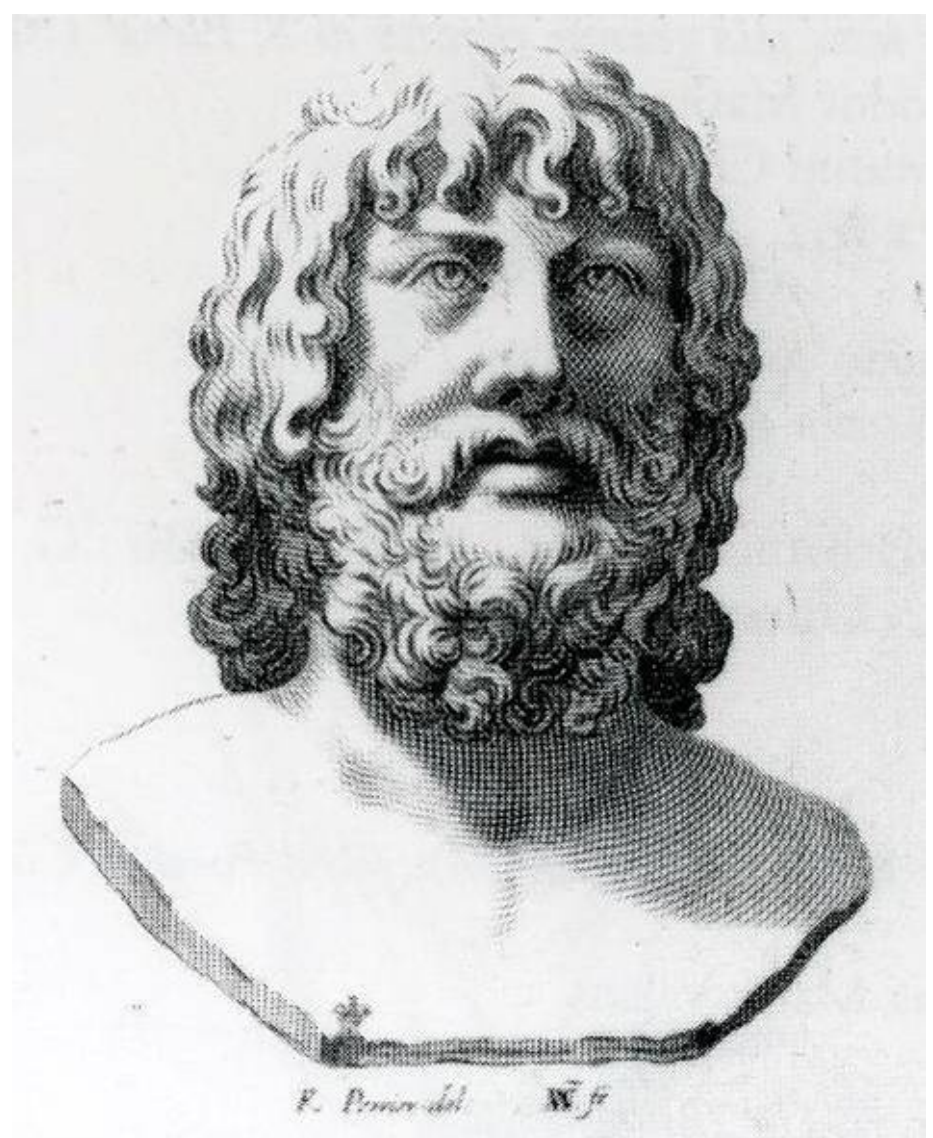

Fig. 7b. Bust of Serapis (Galleria Giustiniana del Marchese Vincenzo Giustiniani. Roma 1631, II tav. 49.1).

Finally an evidence of the adepts of Isis in the territory could come from a statue of a priestess found in 1734 during the construction works for the Casino Corsini. ${ }^{51}$ The statue was restored as Athena by Carlo Antonio Napolioni, who provided an ancient head in his possession and added the right arm with the owl, the left arm and the front part of the foot (fig. 9a), ${ }^{52}$ depending on the Athena Farnese-Hope type, but it does not have the aegis. This iconography was used for many figures of Isis's

${ }^{51}$ DE LUCA, G.: I monumenti antichi di Palazzo Corsini in Roma. Roma 1976, 15-16, no. 1, tavv. I-II. CACCIOTTI: Testimonianze (n. 9) 224, n. 44.

52 Borsellino, E.: Le sculture della Galleria Corsini di Roma: collezionismo e arredo. In KIEVEN, E. - Prosperi VAlenti RodinÒ, S. (edd.): I Corsini tra Firenze e Roma. Aspetti della politica culturale di una famiglia papale tra Sei e Settecento. Atti della giornata di studio, Roma 27-28 gennaio 2005. Milano 2013, 111: "una Pallade alta palmi 7: mancante parte dei piedi braccia pieghe di panno e testa [...] per averci accomodato una mia testa antica con murione...". 


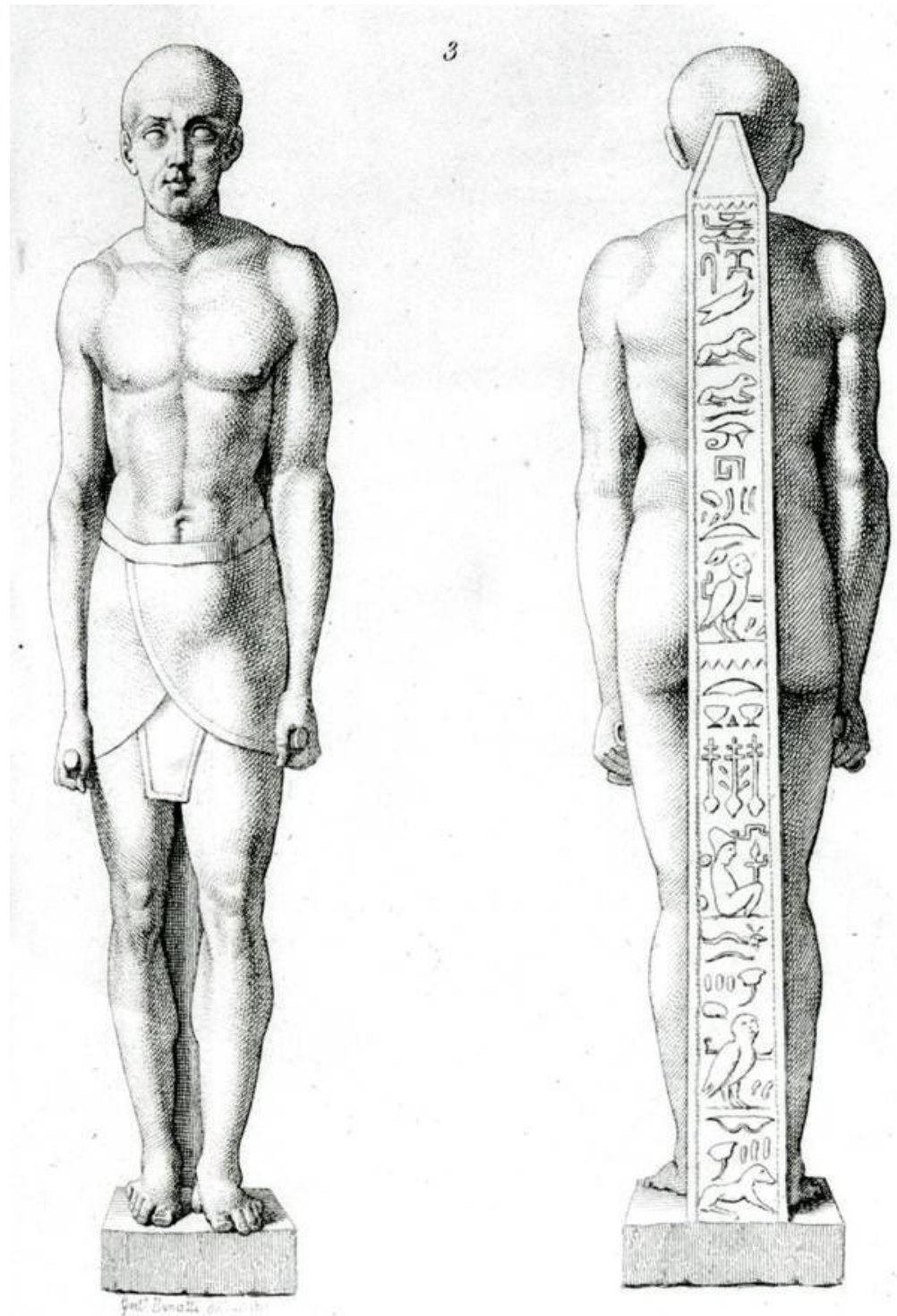

Fig. 8. Isiac Priest from Antium (VISCONTI, E. Q.: Il Museo Worsleyano descritto con prefazione di G. Labus. Milano 1834, tav. XVII, n. 3).

priestesses. They are, usually, characterised by the himation draped under the left armpit and, on the right shoulder, by a brooch to secure it (Typus diplax $=$ a himation folded into double thickness). ${ }^{53}$ We can see a reverse arrangement, as in this statue,

${ }^{53}$ EINGARTNER, J.: Isis und ihre Dienerinnen in der Kunst der Römischen Zeit. Leiden 1991, 8-9, 33 ff.; SCHRÖDER, S. F. : Catálogo de la escultura clásica del Museo del Prado, Madrid 2004, no. 189. 


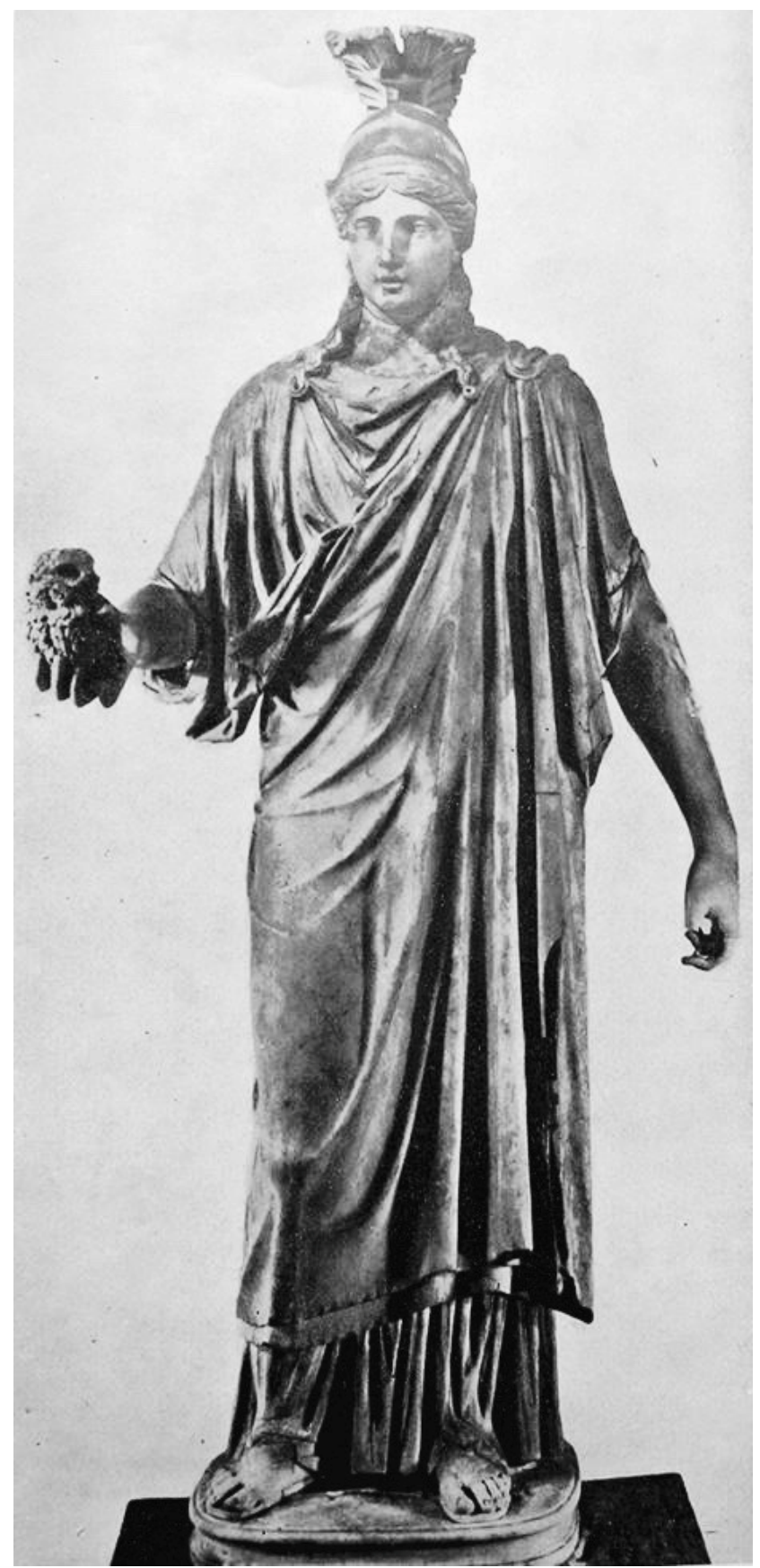

Fig. 9a. Priestess of Isis from Antium. Rome, Corsini Palace (DE LuCA, G.: I monumenti antichi di Palazzo Corsini in Roma. Roma 1976, 15-16, no. 1, tav. I). 


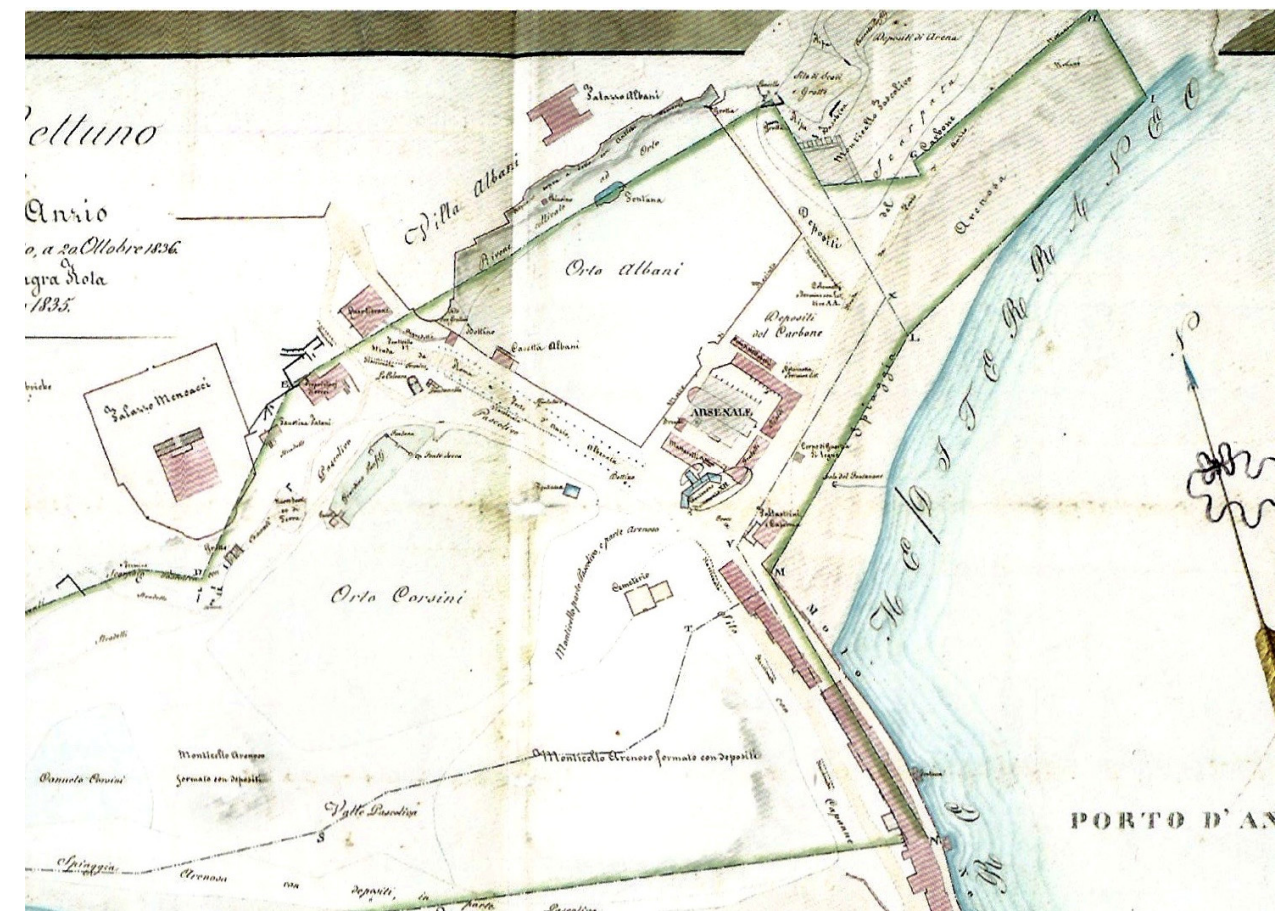

Fig. 9b. Map of Antium, Valley and Port, 1836. Rome, State Archives (MARIGliani, C.: Storia di Anzio, Roma 2008, 172, fig. 2).

in clothing of the palla contabulata used by Isis' adepts. The contabulatio is missing, however, in our statue, but two long curls reminiscent of the 'Isis-locken' are still preserved on the chest and belong to the original hair. The movement of the arms, the right bent and the left down along the side, is similar to that of the Isiacae with the sistrum upward and the situla downward. We can observe these representations on sepulchral monuments, like that of Cantinea Procla and Flavia Stratonice. ${ }^{54}$

It may be possible that this statue comes from a funerary context since a necropolis has been unearthed during the construction works for the Coffee-House of the Corsini family in $1743^{55}$ (fig. 9b). (Beatrice Cacciotti)

${ }^{54}$ This arrangement is mainly on funerary reliefs from Rome and Italy: EINGARTNER (n. 55) 9, no. 132-137, 60, 73 ff., 78-80. For the Cantinea Procla monument at Palazzo Massimo from via Ostiense, cf. Bottini, A.: Il rito segreto. Misteri in Grecia e a Roma. Milano 2005, no. 61. Cf. also the Isis statue discovered by Robert Fagan in Ostia at Tor Boacciana and sold through Vincenzo Pacetti to the Vatican Museums: PAlma Venetucci, B.: Orientalia nello studio di Vincenzo Pacetti (1771-1819). In: Vincenzo Pacetti, Roma, l'Europa all'epoca del Grand tour. Atti del Convegno Internazionale di Roma 28-30 novembre 2013. Roma 2017, 233-245, esp. n. 64.

${ }^{55}$ CACCiOtTI: Testimonianze (n. 9) 224, n. 44. 


\section{MITHRAIC MONUMENTS}

This section of the paper concerns the importance of the cult of Mithras in Antium, as suggested by two Mithraic bas-reliefs discovered in Antium through the 17th-18th centuries and dispersed in different collections; a Dadophorus statue, now in the Ashmolean Museum in Oxford, and an inscription dedicated to Hecate and Mithra, are both supposed by many scholars to have been discovered in Antium.

The Mithraic relief, known from an engraving by Philippe Della Torre (1657$1717)^{56}$ and broken on the upper right corner, where the Moon would have been, ${ }^{57}$ may be the relief described by Francesco Lombardi and found in 1699 where the luoghi cavernosi are, near the right pier of Nero's harbour: ${ }^{58}$ Vermaseren thought it was $\operatorname{lost}^{59}$ (fig. 10a). But in the 19th century the Austrian orientalist Joseph de Hammer-Purgstall (1774-1856) ${ }^{60}$ compared this relief with another one in Palazzo Gioia, once named Buratti, in Rome. ${ }^{61}$ The study of 1814 by the German orientalist Johann Gottfried Eichhorn (1752-1827), which depicted in a table both ${ }^{62}$ the Gioia-Buratti relief and the other relief engraved by Della Torre, assures that the two reliefs are different: the Gioia Buratti relief is very similar to the relief today in the Virginia Museum in Richmond (USA) ${ }^{63}$ (figs $10 \mathrm{~b}-\mathrm{c}$ ).

De Hammer-Purgstall describes another Mithras bas-relief, found in Antium, and preserved in the Sannesio property ${ }^{64}$ In this relief, also published by Della Torre and Montfaucon, ${ }^{65}$ the particularity is that the tail of the bull ended in corn ears and

${ }^{56}$ Della TORRe, F.: Monumenta Veteris Antii. Romae 1700, 157 ff .VII, esp.VI 85; CACCIOTTI: Testimonianze (n. 9) 222.

${ }^{57}$ Georg Zoegas Abhandlungen. Herausgegeben und mit Zusätzen begleitet von F. G. WELCKER. Göttingen 1817, 150, no. 27. DE MONTFAUCON, B.: L'Antiquité expliquée et représentée en figures. $2^{\mathrm{e} m e}$ éd. Paris 1722, 379, tav. CCVXI 2.

${ }^{58}$ LOMBARDI, F.: Anzio antico e moderno. Roma 1865, 143-144.

${ }^{59}$ VERMASEREN, M. J.: Corpus inscriptionum et monumentorum religionis Mithriacae [CIMRM]. Vol. I. Den Haag 1956, fig. 64, no. 204.

${ }^{60}$ DE HAMmer-Purgstall, J.: Mithriaca ou les mithriaques. Paris 1833, 82 no. IV. “de 1'ancienne Antium (Nuno) publié par Philippe Della Torre et par Eichorn. Ce monument se trouve dans le palais Pioja, devant le Burazzi. Le chien et le serpent attaquent le taureau par devant. La partie ou devait se trouver la Lune est mutilée; le soleil se voit en buste, la tète environnée de rayons".

${ }^{61}$ Mangiafesta, M.: Georg Zoëga e alcuni rilievi del culto mitriaco. Annali della Pontificia Insigne Accademia di Belle Arti e Lettere dei Virtuosi al Pantheon 15 (2015) 480-481, fig. 3.

${ }^{62}$ EICHORN, J. G.: De deo Sole invicto Mithra commentatio. Gottinga 1814, figs 2-3.

${ }^{63}$ WelcKer (n. 57) 149, no. 21; CIMRM 210, no. 533 (h cm 70; $1 \mathrm{~cm} \mathrm{96);} \mathrm{VermeUle,} \mathrm{C.} \mathrm{C.:}$ Greek and Roman Sculpture in America. Masterpieces in Public Collections in the United States and Canada. Berkeley - Los Angeles - London 1981, 236 no. 197 (h cm 79×99).

${ }^{64}$ DE Hammer-Purgstall (n. 60) 82, no. V. "Le monument trouvé à Anzio (Ducis Sannesi) également publié par Philippe Della Torre et par Montfaucon, n’offre rien de particulier, excepté que la queue du taureau est terminée en epis et que le soleil et la lune sont représentés en médaillons. On voit aussi au dos de Mithra le foureau dont il a tiré le poignard". Sannesio was a noble Roman family from Marche risen to a high dignity under Pope Clement VIII Aldobrandini, who took up residence in Rome at Palazzo Maffei-Sannesio-d'Este-Acciajoli-Marescotti in Via della Pigna, today the seat of the Vicariate. CARPAnetO, G.: I palazzi di Roma. Roma 1998, 298; ZACCAGNINI, C.: Le ville di Roma. Roma 1991, 195.

${ }^{65}$ Della TORRE (n. 56) VIII 87. De MONTFAUCON (n. 56) I 117. 


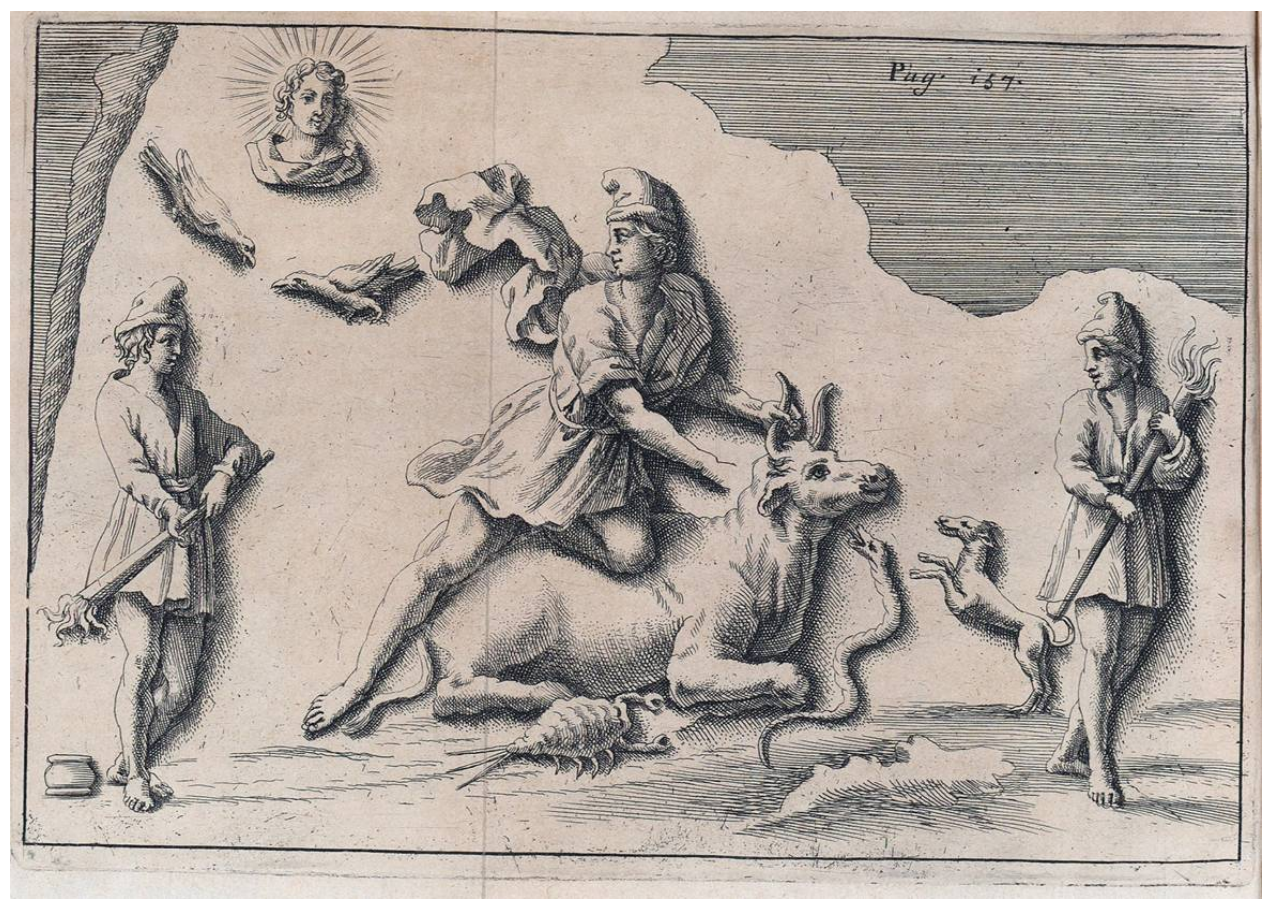

Fig. 10a. Mithriac relief, from Porto d'Anzio

(Della TORRe, F.: Monumenta Veteris Antii. Romae 1700).

the sun and the moon are inserted in two medallions. This bas relief may be the relief today in the Museo Maffeiano Lapidario in Verona. ${ }^{66}$ The bust of the sun has a radiant crown and the bull's tail ends in corn ears; but other scholars say that this is the relief excavated in 1699 at Porto d'Anzio and published by Della Torre, that arrived in Verona through Francesco Bianchini. ${ }^{67}$ Perhaps we can also see the bas relief in the lower right corner of a drawing (1730) by Giambettino Cignaroli of Verona (1706$1770)^{68}$ (figs 11a-b).

Finally a statue of a Dadophorus, now in the Ashmolean Museum of Oxford, without the restorations by Guelfi, a scholar of Camillo Rusconi (right arm, lower legs

${ }^{66}$ MAfFeI, S.: Museum Veronense. Verona 1749, LXXV 1. CECCARINI, T. (ed.): Anzio e $i$ suoi Fasti. Il tempo tra mito e realtà. Catalogo della mostra. Anzio 2010, no. 19, 115 (M. Bolla). JAJA, A. M.: I luoghi dei Fasti. Appunti di topografia anziate. In CECCARINI 25-31, esp. 25-26. CHIOFFI, L.: Epigrafi tra Roma e Anzio. Note a margine. Rendiconti della Pontificia Academia Romana di Archeologia 88 (2016) 434-442.

${ }^{67}$ CUMOnT, F.: Textes et monuments figurés relatifs aux mystères de Mithra. Vol. II. Bruxelles 1896, 265, no. 111. CECCARINI (n. 66) no. 19, 114-117 (M. Bolla). But the Documents examined by MirandA, S.: Francesco Bianchini e lo scavo farnesiano del Palatino (1720-1729). Milano 2000, not mention the relief.

${ }^{68}$ Milano, Pinacoteca Ambrosiana, F 256 inf. n. 146; CECCARINI (n. 66) no. 19, 115 (M. Bolla). Dizionario Biografico degli Italiani, vol. 25, s.v. Cignaroli. 


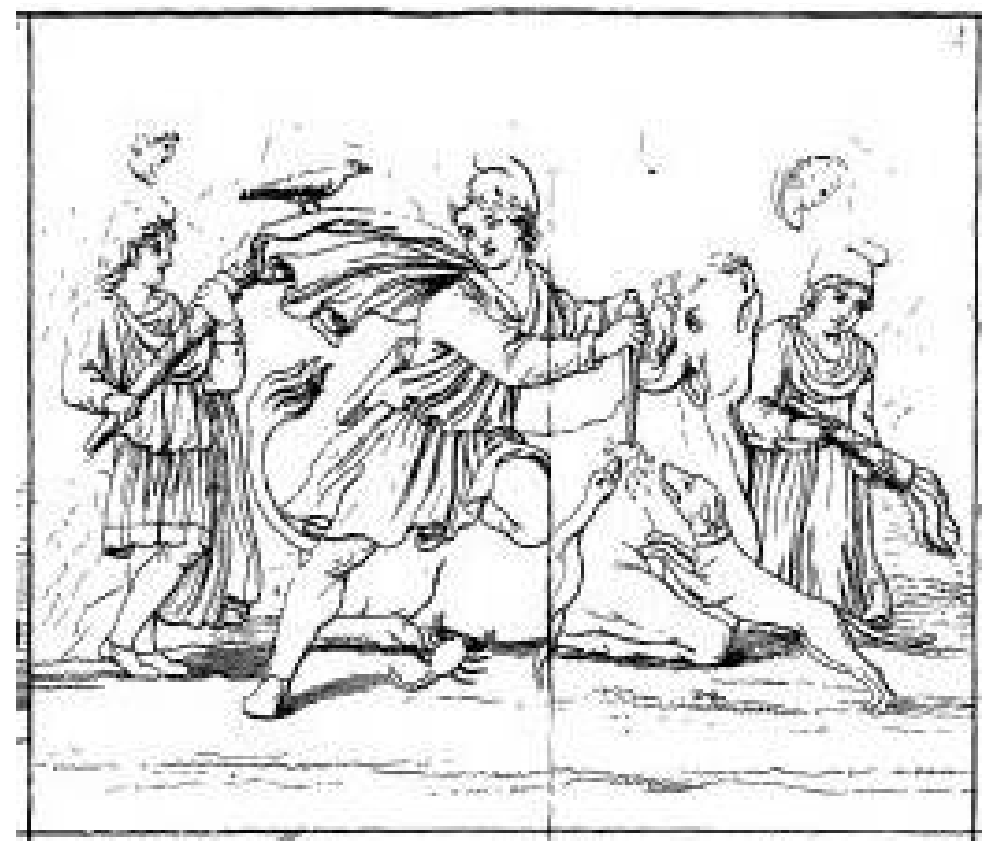

Fig. 10b. Mithriac relief. Palace Gioia Buratti

(EICHORN, J. G.: De deo Sole invicto Mithra commentatio. Gottinga 1814).

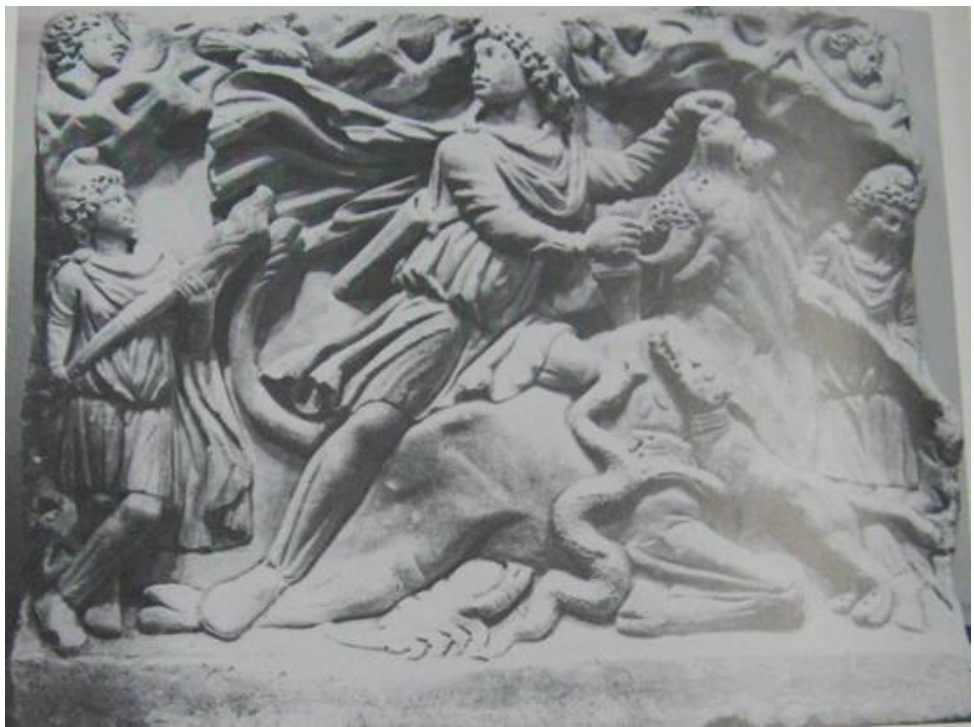

Fig. 10c. Mithriac relief. Virginia Museum USA

(VermeUle, C. C.: Greek and Roman Sculpture in America.

Masterpieces in Public Collections in the United States and Canada.

Berkeley - Los Angeles - London 1981, 236 no. 197). 


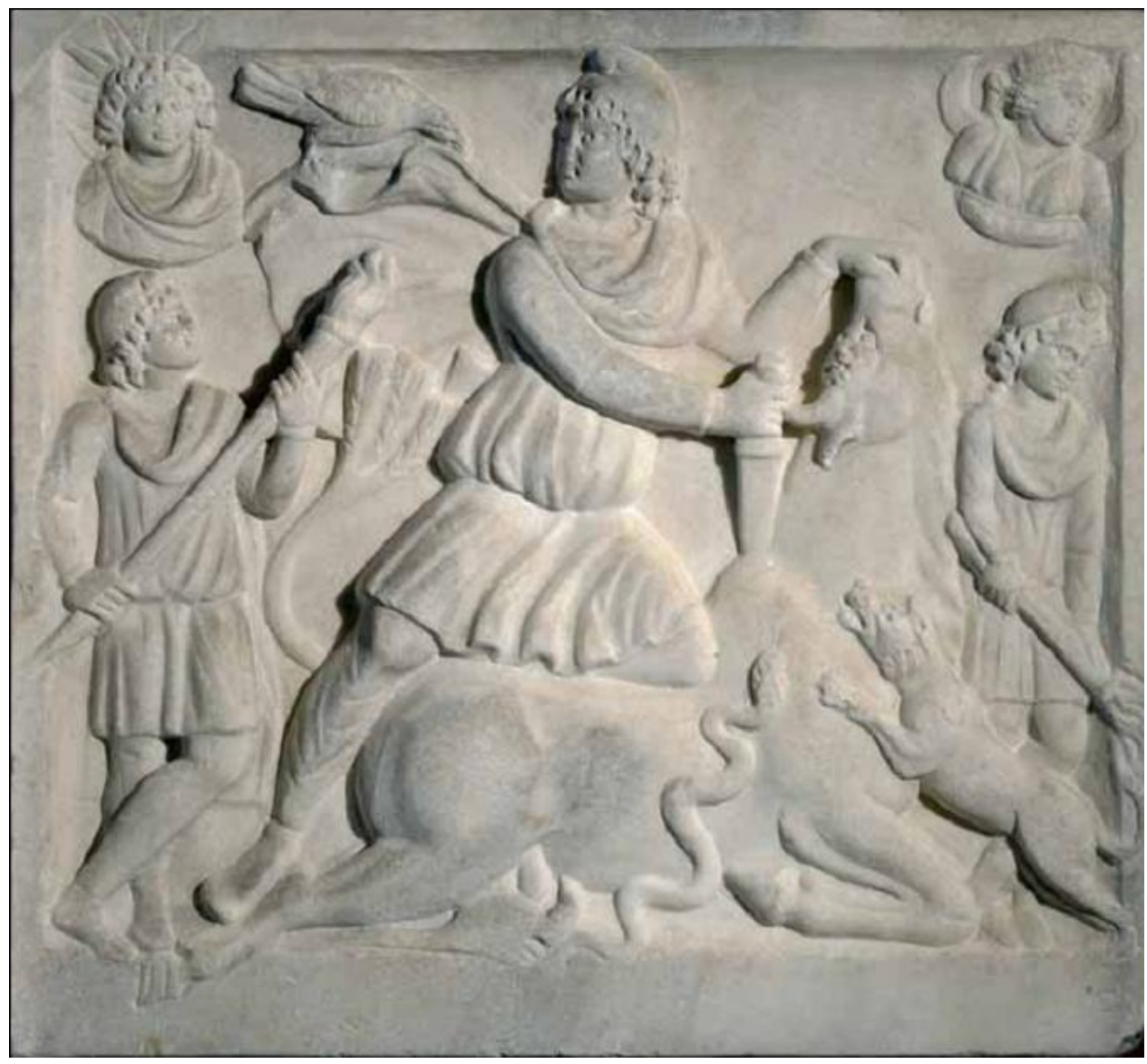

Fig. 11a. Mithriac relief Maffei, from Anzio

(CECCARINI, T. [ed.]: Anzio e i suoi Fasti. Il tempo tra mito e realtà.

Catalogo della mostra. Anzio 2010, no. 192).

with feet, part of the tree trunk), in Pentelic marble and $1.12 \mathrm{~m}$ high, (figs 12a-b) was discovered in Antium, according to Vermaseren and many others scholars, was donated to the Museum in 1755 by the Dowager Henriette Countess of Pomfret. ${ }^{69}$ Unfortunately there are no documents proving the provenance from Antium: we only know that the Dadophorus was given to the museum by Dowager of Pomfret, who inherited, from her father-in-law, part of the collection of Lord Arundel. Lord Arundel formed his collection certainly in Italy, but we have no proof for an Antiate origin of the Dadophorus.

${ }^{69}$ ChandleR, M.: Marmora Oxoniensia. Oxford 1763, no. 20; MiCHAELIS, A.: Ancient Marbles in Great Britain. Cambridge 1882, no. 48; CIMRM I 11, no. 205, fig. 65; BRANDIZZI VITTUCCI (n. 26) 38, fig.17; CACCIOTTI: Gli scavi (n. 3), 26, n. 6. 


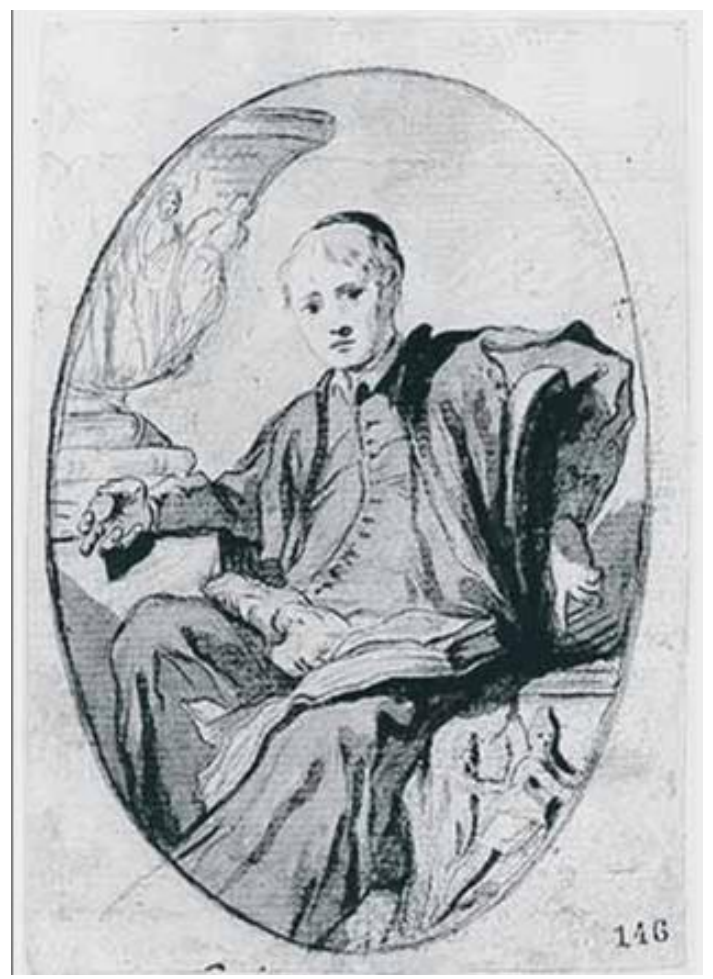

Fig. 11b. Mithriac relief. Drawing by Giambettino Cignaroli (CECCARINI, T. [ed.]: Anzio e i suoi Fasti. Il tempo tra mito e realtà. Catalogo della mostra. Anzio 2010, no. 192).

An inscription relating "to Mithras" mentioning a Freedman of the time of Augustus, Prince of the priests of Hecate and priest of the unconquered Sun Mitra; was found, according to Father Lombardi, ${ }^{70}$ under the Temple of Apollo, near the Nero's harbour, the lighthouse and the imperial Villa, where also the Mithraic relief was discovered in luoghi cavernosi. The inscription, also copied by Ligorio, ${ }^{71}$ in the opinion of many scholars, was not discovered in Anzio and is fake. ${ }^{7}$

A fresco representing Mithras was also discovered in the 19th century but quickly reburied in a mithraeum with its vault supported by four pillars, and a central

${ }^{70}$ LOMBARDi (n. 58) 143-147. "Nei sotterranei di questo tempio Apollineo eravi lo spelaeum, antro o caverna ... Ciò argomentano il Ligorio, il della Torre, ed il Volpi dalla tavola Mithriaca disotterrata... Oltre la tavola Mithriaca, vi si discoprì anche la lapide seguente: HECATE SACRVM/T.FLAVIVS ONCHESTVS AVG.LIB./SACERDOS SOLI INVICTO MITHRAE/HIEROPHANTA HECATE/ ARCHIBVCVLVS/DEI PATRIS LIBERI ET/HIEROCERYX DEI SOLI PACIFERO/XIII SACERDOS COOPTAT : COLL : AN : FERON.".

${ }^{71}$ Copied by P. Ligorio (Torino Archivio di Stato, P. Ligorio, Libri dell'antichità, Cod. A. III 11. J. 9, s.v. Hecate), "che parla di sacerdoti e sacrifizi fin da tempi di Augusto".

${ }^{72}$ CIL VI 5, 312*. 


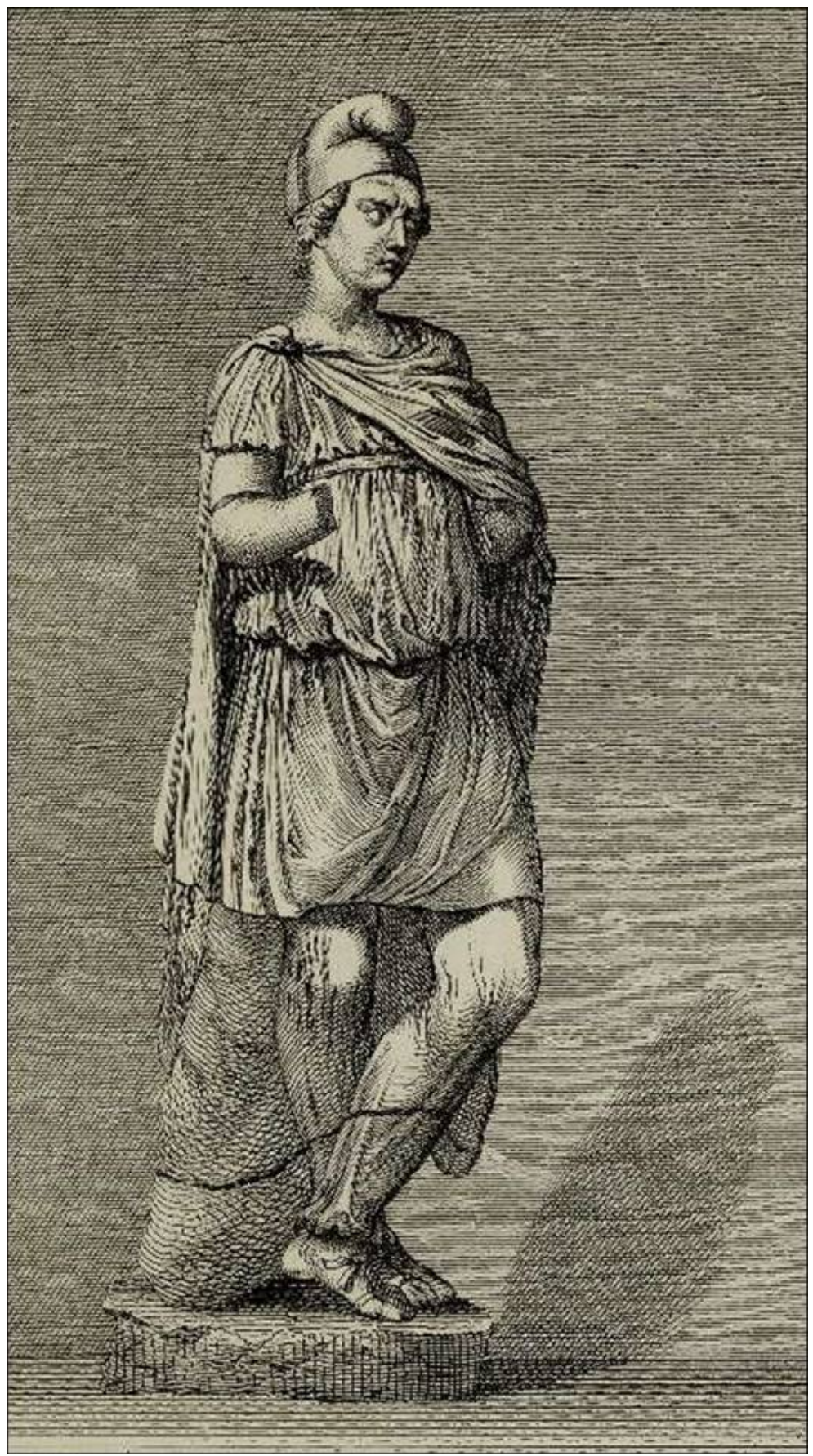

Fig. 12a. Dadophorus. Drawing

(Chandler, M.: Marmora Oxoniensia. Oxford 1763, no. 20). 


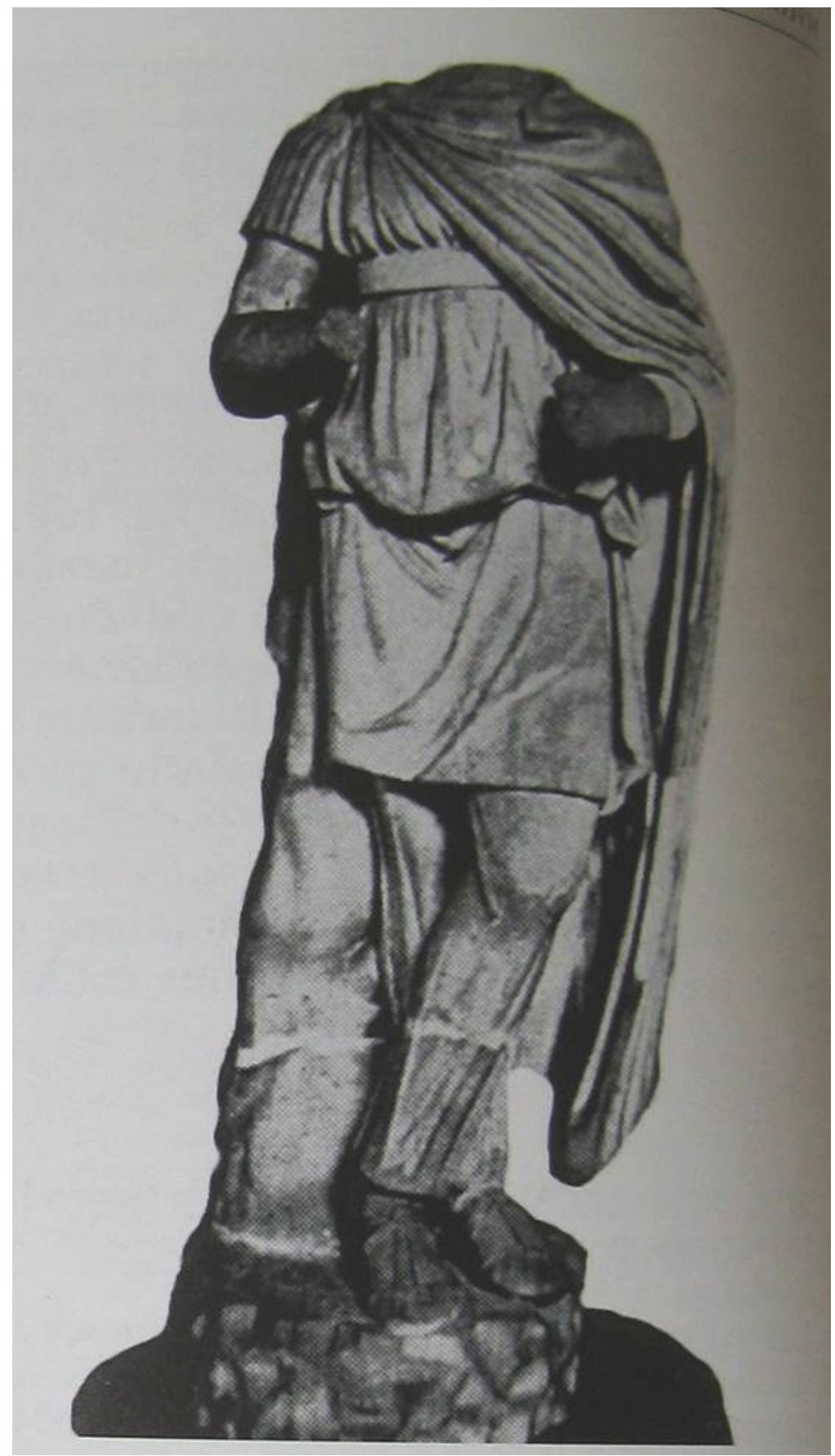

Fig. 12b. Dadophorus, Oxford Ashmolean Museum (BRANDIZZI ViTTUCCI, C.: Antium: Anzio e Nettuno in epoca romana. Roma 2000, 38, fig. 17). 
altar, in the area of the Aldobrandini-Sarsina Villa. ${ }^{73}$ It may have been in the former Corsini stables, or beneath the Villa Serena, (the Salpietro former palace) ${ }^{74}$ in front of the former Magistrates Court, at the beginning of via Ambrosini.

The purpose is to relate the two Mithraic reliefs, discovered in Antium, to different Mithraic caves: the one near Nero's harbour and the imperial Villa, the so called Grotte di Nerone, the other in the area of the Villa Aldobrandini-SarsinaSerena. These can suggest new research in order to find a sure provenance for the Sannesio- Maffei relief and other reliefs supposed to have been discovered in Anzio. For example a Ludovisi relief, mentioned in Ludovisi's first inventory of 1623, may come from the collection of Bartolomeo Cesi who had a villa in Anzio and a land where he discovered many antiquities. ${ }^{75}$ The Cesi Collection was partially sold to the Ludovisi family. ${ }^{76}$

Finally, it is very important to remember that, although all the monuments examined are out of context and the actual place of worship has never been identified, mithraea are located often in neighbourhoods shared by Isiac temples, because many cultic aspects are shared by both the Isiac and Mithraic cults, and both are often connected to private villas. Perhaps the different lectures presented in this Symposium can reinforce this hypothesis with the location of Isiac cults near Mithraic cults in Antium and also near a bath complex. (Maria Mangiafesta)

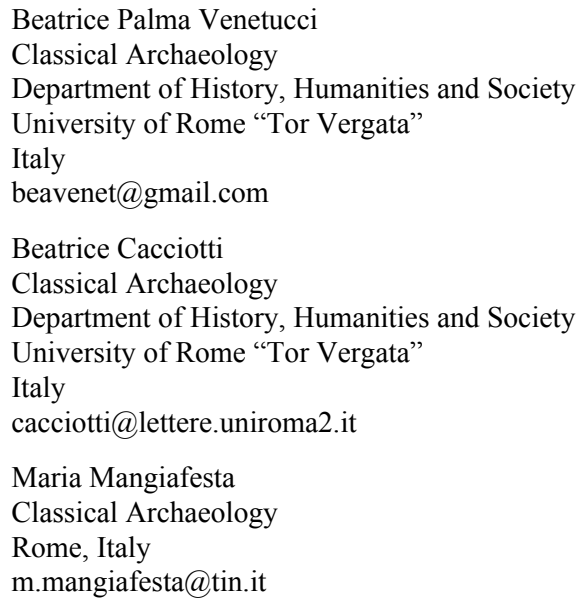

${ }^{73}$ CHIARUCCI, P.: Anzio archeologica. Anzio 1989, 58; JAIA, A. M.: I luoghi di culto del territorio di Anzio, Lazio e Sabina, 2. Secondo incontro di studi sul Lazio e la Sabina. Atti del convegno, Roma 7-8 maggio 2003. Roma 2004, 255-264, esp. 256.

${ }_{74}$ CHIARUCCI (n. 73).

75 Supra no. 26.

${ }^{76}$ PALMA - De LachenAL - Micheli (n. 11) II 9, VIII 24. PALMA VenetuCCi, B.: Le collezioni di Antichità dei Cesi a Roma. In Atti del Convegno di Studi: I Cesi di Acquasparta, la Dimora di Federico il Linceo e le Accademie in Umbria nell'età moderna. Palazzo Cesi Acquasparta, 26 settembre - 24 ottobre 2015. Perugia 2017, 195, fig. 13. 
